\title{
16. PETROLOGY AND GEOCHEMISTRY OF BASALTIC CLASTS AND HYALOCLASTITES FROM VOLCANICLASTIC SEDIMENTS AT SITE 869 ${ }^{1}$
}

\author{
P.E. Janney ${ }^{2}$ and P.E. Baker ${ }^{3}$
}

\begin{abstract}
The petrography, mineralogy, and geochemistry of 11 basaltic clasts and 12 hyaloclastites from volcaniclastic sediments sampled at Ocean Drilling Program (ODP) Site 869 are described. Radiometric dates indicate that the basaltic clasts are of Cenomanian age (94-96 Ma), making them the oldest igneous samples yet recovered from Pikinni Atoll or Wodejebato Guyot.

The clasts are all hypocrystalline porphyritic basalts and are divided into three groups, based on their phenocryst assemblages and textural characteristics. The hyaloclastites are composed of glass shards, mineral fragments, and lithic fragments in a matrix of zeolite minerals. Mineral compositions are typical of phases crystallized from mildly to moderately alkalic melts.

The clasts have the high incompatible element concentrations and light rare earth element enrichments typical of alkalic ocean island basalts (OIB). They form linear arrays on incompatible element vs. incompatible element and incompatible element vs. ratio of highly to moderately incompatible element ( $\mathrm{H} / \mathrm{M}$ ratio) diagrams. These arrays appear to be controlled by both variations in degree of partial melting and by changes in the composition of the mantle source. Ratios of trace elements in the clasts, especially $\mathrm{Nb} / \mathrm{Zr}$, suggest that the mantle source of the clasts was heterogeneous, with compositions ranging from Samoa- to Tubuai-like (i.e., from EMII to HIMU). This type of mantle source variation is consistent with isotopic data on the Site 869 clasts presented elsewhere.

Paleontological and radiometric age data suggest that volcanism at Pikinni/Wodejebato occurred in two main stages and that the Site 869 clasts are products of the first stage of volcanism; this suggests that the shields of the Pikinni and Wodejebato edifices are composed of mildly to moderately alkalic lavas.
\end{abstract}

\section{INTRODUCTION}

During the Early to mid-Cretaceous period, widespread hot spot volcanism created a large number of volcanic plateaus, seamounts, and islands on oceanic crust that now lies in the western Pacific region. Concurrent with this volcanism was the shedding of volcanic debris from the slopes of the volcanoes, via mass flow and turbidity currents, onto adjacent apron and basinal areas, where it was deposited as volcaniclastic sediment (e.g., Kelts and Arthur, 1981). For this reason, Cretaceous volcanogenic sediments are present throughout large areas of the western Pacific and have been sampled at a number of Deep Sea Drilling Project (DSDP) and ODP drilling sites (e.g., Floyd, 1986).

Site 869 is one of these drilling sites where sampled sequences of volcaniclastic sediments were derived from nearby volcanic edifices. Site 869 is located approximately $83 \mathrm{~km}$ southwest of the Pikinni/ Wodejebato atoll-guyot pair in the western Ralik chain of the Marshall Islands (Fig. 1). Although Pikinni and Wodejebato are considered to be two separate edifices, the two features are located closely to one another and are connected by a shallow $20-\mathrm{km}$-long volcanic ridge (Fig. 1B; Bergersen, 1993). Therefore, because of the proximity of Pikinni Atoll to Wodejebato Guyot and because the location of Site 869 was chosen so as to sample volcanic debris derived from both features (Sager, Winterer, Firth, et al., 1993), we treat Pikinni Atoll and Wodejebato Guyot as a single volcanic feature, designated as Pikinni/Wodejebato, for the purposes of this study.

Site 869 lies on the archipelagic apron that surrounds Pikinni/ Wodejebato; drilling at the site penetrated a 600 -m-thick sequence of volcaniclastic sediments, derived from turbidity currents and grain and debris flows from the flanks of the atoll-guyot pair (Sager, Winterer, Firth, et al., 1993). Wodejebato Guyot has been dated by

${ }^{1}$ Winterer, E.L., Sager, W.W., Firth, J.V., and Sinton, J.M. (Eds.), 1995. Proc. ODP, Sci. Results, 143: College Station, TX (Ocean Drilling Program).

${ }^{2}$ Geological Research Division, Scripps Institution of Oceanography, University of California, San Diego, La Jolla, CA 92093-0220, U.S.A.

${ }^{3}$ Department of Earth Sciences, University of Leeds, Leeds LS2 9JT, United Kingdom. radiometric and paleontological methods and is reported to be midCretaceous in age (Pringle and Duncan, this volume; Pringle et al., 1993; Lincoln et al., 1993) with a wide range of ages for volcanic rocks (96-79 Ma). Interestingly, the basaltic clasts recovered from Site 869 are the oldest dated volcanics yet recovered from Pikinni/ Wodejebato (Pringle, et al., 1993; Pringle and Duncan, this volume).

This study describes the petrographic, mineralogical, and geochemical characteristics of 11 large $\left(>30 \mathrm{~cm}^{3}\right)$ basaltic clasts and 12 pieces of hyaloclastite matrix extracted from volcaniclastic sediments recovered from Site 869 . We have four main objectives in this study: (1) to determine the petrologic affinity of Site 869 volcanic clasts and hyaloclastites and to describe the major petrogenetic processes that influenced their magmatic evolution; (2) to describe qualitatively the type of mantle source that could have produced the clasts; (3) to compare the mineralogy, petrography, and composition of the basaltic clasts and hyaloclastites with other lavas recovered from Pikinni/ Wodejebato and lavas recovered from the other Marshall Islands; and (4) to compare the geochemistry of the volcanic rocks from Site 869 to other Pacific hot spot volcanoes. The isotope geochemistry of the Site 869 clasts will be presented elsewhere (Castillo et al., unpubl. data).

The sediments at Site 869 are divided into three stratigraphic units: Units I and II comprise a 200 -m-thick sequence of pelagic radiolarian/nannofossil oozes, porcellanites and cherts; Unit III is made up of a 600 -m-thick sequence of volcaniclastic siltstones, sandstones, and breccias intercalated between nannofossil and radiolarian claystones (Fig. 2; Sager, Winterer, Firth, et al., 1993). The volcaniclastic sediments in Unit III are mostly sand and silt-sized, made up of lithic fragments, glass shards, and mineral grains deposited by turbidity currents. Pebble- and cobble-sized clasts are concentrated in volcanic breccia sequences in the interval at 488-653 mbsf (Subunits IIID and IIIE of Sager, Winterer, Firth, et al. [1993]), apparently as the products of grain and debris flows. These breccia layers are made up of large volcanic clasts that range in size up to $80 \mathrm{~mm}$, with finer volcanogenic sediments, including hyaloclastites, and secondary minerals filling the interstices. The hyaloclastites are composed of shards of volcanic glass and mineral grains cemented in a matrix of secondary minerals (mostly zeolite) and occur both in the breccia layers and in the turbidite sequences. Most of our samples come from the volcanic 
Figure 1. A. Regional bathymetric map of the Marshall Islands. Small square shows area covered by location map. B. Location map of Site 869, showing its relative position to Pikinni Atoll and Wodejebato Guyot.

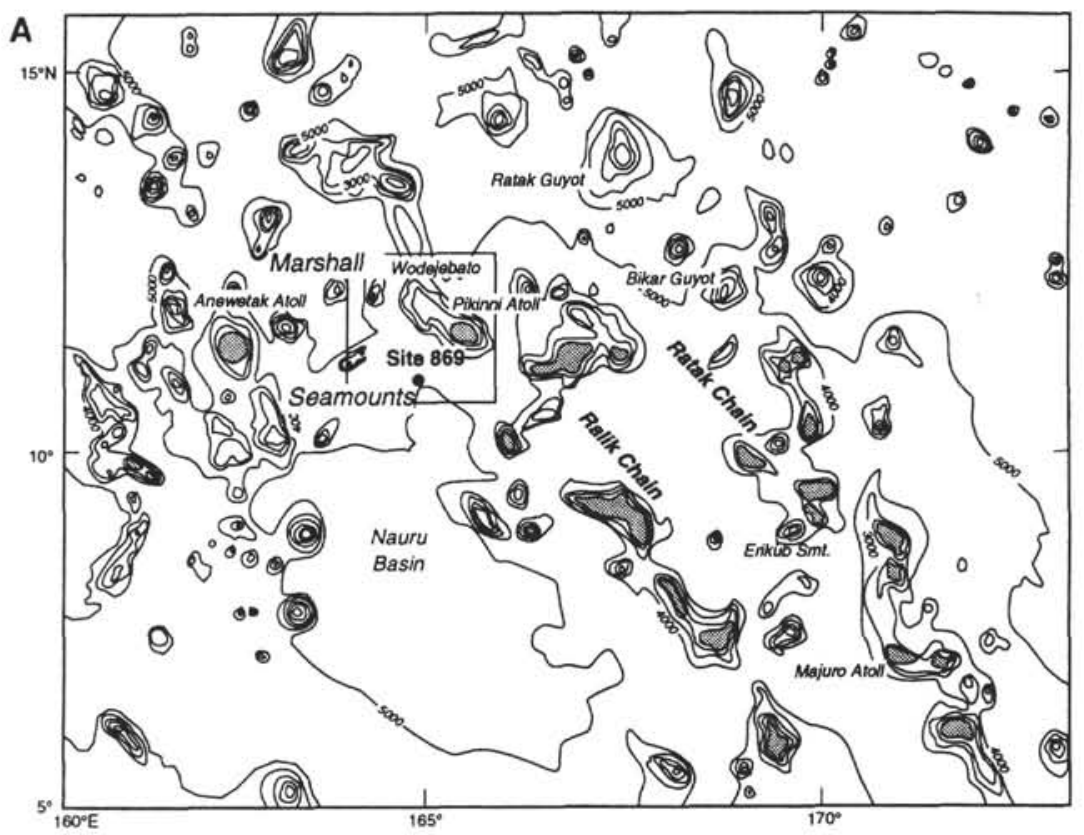

breccia layers (Cores 143-869B-39R to -55R) because the large size of the clasts in these layers allows us to use them for whole-rock geochemical analysis.

\section{PETROGRAPHY OF BASALTS AND HYALOCLASTITES}

The stratigraphic position and lithology of the 23 samples analyzed are shown in Figure 2. Ten of the samples are porphyritic hypocrystalline basalts, one is a porphyritic hypocrystalline hawaiite, and the other 12 are hyaloclastites composed of cemented glass and mineral fragments.

The clasts are separated into three groups on the basis of their phenocryst assemblages and textures. The groups, in approximate stratigraphic order (top to bottom) are (1) moderately to highly clinopyroxene, olivine, and plagioclase phyric; (2) moderately hornblende, clinopyroxene, and plagioclase phyric; and (3) moderately clinopyroxene and plagioclase phyric (see Table 1 for modal data and petrographic designations).

\section{Group 1 (Moderately to Highly Clinopyroxene, Olivine, and Plagioclase Phyric)}

The five Group 1 basalts are notable for having the highest modal percentage of phenocrysts of the four groups, averaging about $10 \%$ by volume. The phenocryst assemblages of these rocks are dominated by euhedral plagioclase phenocrysts and microphenocrysts $(0.1-2 \mathrm{~mm} ; 5$ vol\% average), subhedral to euhedral olivine phenocrysts and microphenocrysts $(0.25-1 \mathrm{~mm} ; 4 \mathrm{vol} \%$ average $)$, and subhedral clinopyroxene phenocrysts and microphenocrysts $(0.1-0.75 \mathrm{~mm} ; 1$ vol\% average). Normal zoning is commonly observed in the larger plagioclase phenocrysts. Olivine grains are pristine in one sample (143-869B$41 \mathrm{R}-4,70-73 \mathrm{~cm})$, have been about $50 \%$ replaced in another (143$869 \mathrm{~B}-42 \mathrm{R}-2,84-86 \mathrm{~cm}$ ), and have been totally replaced by green and brown smectite in the other three. Near-hexagonal pseudomorph outlines allow one to identify olivine in the samples where it has been replaced. The groundmasses of Group 1 samples are composed of devitrified glass (45 vol\% average), plagioclase laths (34 vol\% average), and anhedral clinopyroxene grains ( $4 \mathrm{vol} \%$ average). Four of the five Group 1 basalts are vesicular ( $<1$ to $25 \mathrm{vol} \%$ ), with a vesicle size range of 0.1 to $5 \mathrm{~mm}$. Most of the vesicles are rimmed with smectite and filled with zeolite or, less commonly, calcite.

\section{Group 2 (Moderately Hornblende, Clinopyroxene, and Plagioclase Phyric)}

Group 2 is represented by a single nonvesicular clast in Sample 143-869B-41R-5, 82-85 cm, classified as a hawaiite (based on its plagioclase compositions and high concentrations of incompatible trace elements, such as $\mathrm{Nb}$ and $\mathrm{Zr}$ ). Its phenocryst assemblage is dominated by euhedral plagioclase phenocrysts and microphenocrysts $(0.2-1 \mathrm{~mm} ; 7 \mathrm{vol} \%)$ and subhedral to anhedral clinopyroxene phenocrysts and microphenocrysts $(0.1-1 \mathrm{~mm} ; 1 \mathrm{vol} \%)$. Normally and oscillatorily zoned plagioclase phenocrysts are common. About half of the clinopyroxene phenocrysts are arranged in loose aggregates of three to five grains, with edges touching or just slightly separated. The clinopyroxene grains are also commonly twinned. Anhedral hornblende phenocrysts and microphenocrysts $(0.25-0.75 \mathrm{~mm} ;<1 \mathrm{vol} \%)$ are present, but extremely rare. The groundmass consists of plagioclase laths (32 vol\%) with a trachytic texture, subhedral to euhedral opaque phases $(0.02-0.1 \mathrm{~mm} ; 2 \mathrm{vol} \%)$, sparse anhedral clinopyroxene grains $(0.05-0.1 \mathrm{~mm} ;<1 \mathrm{vol} \%)$, and devitrified glass ( $57 \mathrm{vol} \%)$.

\section{Group 3 (Moderately Clinopyroxene and Plagioclase Phyric)}

The five basalts in this group are all plagioclase and clinopyroxene phyric, with a small average phenocryst content of about $5 \mathrm{vol} \%$. Subhedral plagioclase phenocrysts and microphenocrysts $(0.1-0.7 \mathrm{~mm}$; 4 vol\% average) outnumber the fewer, mostly anhedral clinopyroxene phenocrysts and microphenocrysts $(0.1-1 \mathrm{~mm} ; 1 \mathrm{vol} \%$ average), which are commonly sector-zoned. The groundmasses of Group 3 basalts are composed of subhedral plagioclase laths ( $56 \mathrm{vol} \%$ average), anhedral clinopyroxene ( 9 vol\% on average), and devitrified glass (26 vol\% average). Three of the five Group 3 samples are vesicular $(5-15 \mathrm{vol} \%)$. Vesicle size and shape range from small $(0.5$ $\mathrm{mm})$ and spherical to large $(3 \mathrm{~mm})$ and irregular. The vesicles are typically rimmed with green smectite and filled with zeolite or, less commonly, calcite or clay minerals.

\section{Hyaloclastites}

The petrographic characteristics of hyaloclastites are discussed separately from the basaltic clasts for two reasons: (1) the hyaloclastite samples are amalgamations of many individual fragments that 


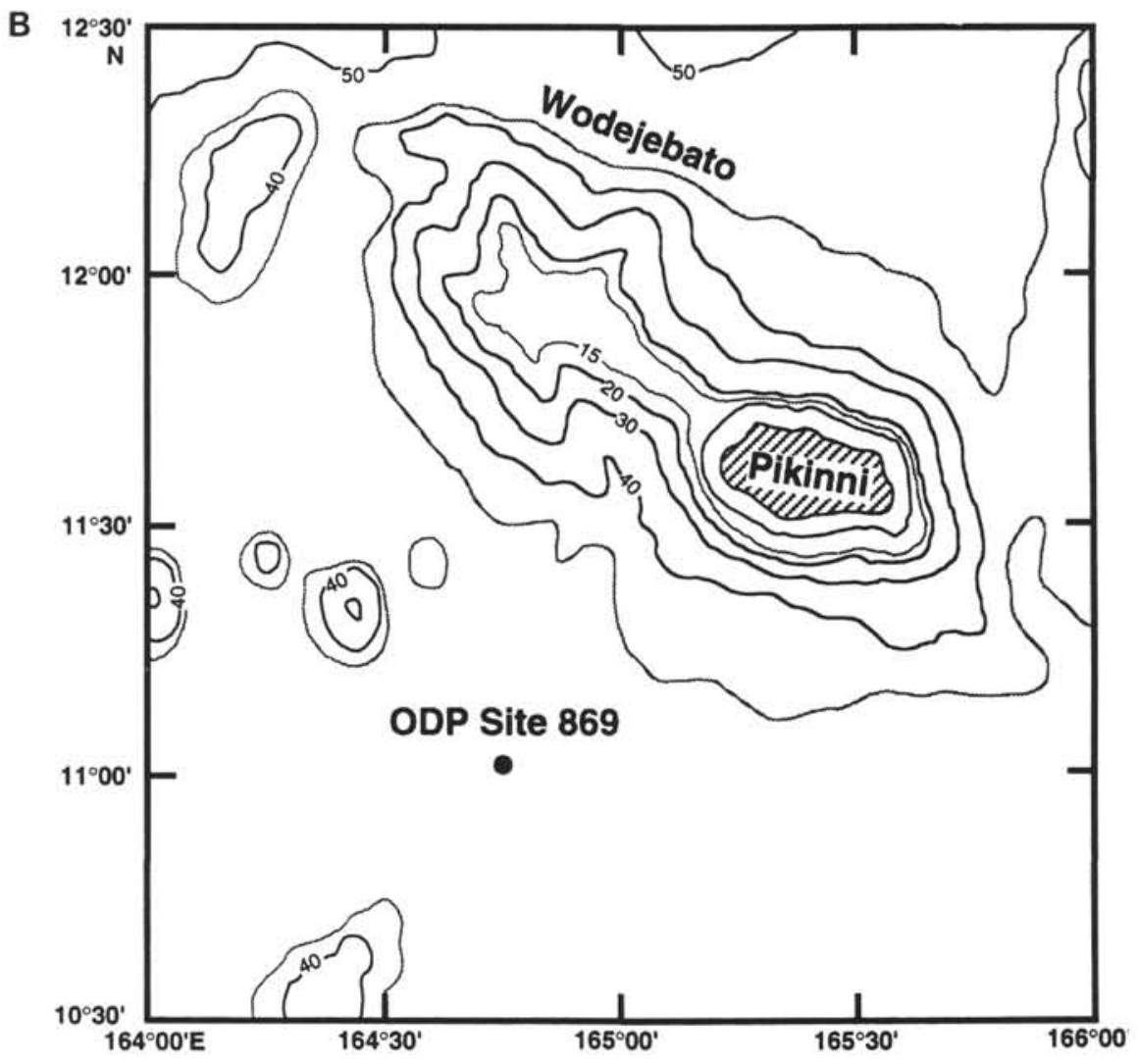

Figure 1 (continued).

were only combined upon deposition, and thus the phenocryst mineralogy and textural characteristics of a hyaloclastite, unlike a basalt clast, generally have limited petrologic significance; (2) the texture and mineralogy of the individual fragments in the hyaloclastites are different enough from the basalts that the hyaloclastites do fit into any of the 3 groups described above. Nevertheless, the hyaloclastite samples are similar enough to each other that a number of general characteristics can be observed and discussed. By far, the most common constituents of the hyaloclastites are light yellow or yellow green to brown glass fragments (hyaloclasts). Some of the difference in coloration results from varying degrees of palagonitization. These glass fragments range in size from tiny shards less than $0.1 \mathrm{~mm}$ to large lapilli up to $10 \mathrm{~mm}$ in length and make up $65 \%$ to $90 \%$ of the hyaloclastites by volume. The hyaloclasts are variably vesicular $(0-20$ vol\%), with small vesicles $(0.05-0.25 \mathrm{~mm}$ in diameter) that are occasionally rimmed with green smectite and are rarely filled with zeolite or clay minerals. The larger lapilli often contain one or more phenocryst grains.

By far, the most common type of phenocryst is olivine (4-6 vol\%). The olivine grains are of variable size $(0.2-2 \mathrm{~mm})$ and are mostly euhedral and pristine, although about a quarter of them are skeletal, and a few have inclusions of glass and/or $\mathrm{Cr}$-spinels.

The largest lapilli ( $>5 \mathrm{~mm}$ ) may contain glomerocrysts of five to eight olivine microphenocrysts $(0.2-0.5 \mathrm{~mm})$, often accompanied by several tiny $(<0.05 \mathrm{~mm}) \mathrm{Cr}$-spinel grains. The other common phenocrysts are plagioclase $(<1-2 \mathrm{vol} \%)$, which most often forms thin laths $(0.05-0.5 \mathrm{~mm}$ long $)$ that penetrate the glass in random directions, $\mathrm{Cr}$-spinel, which most often appears as small $(0.1 \mathrm{~mm})$ euhedral grains usually adjacent to olivines, and clinopyroxene $(<1-2$ vol\%), which tends to form subhedral grains of small to moderate size $(0.2-0.7 \mathrm{~mm})$.

Mineral fragments, which we define as individual mineral grains without any attached glass, make up about 5 to $10 \mathrm{vol} \%$ of the hyaloclastites. They tend to be smaller than the lapilli phenocrysts, and many of the grains have rounded corners, presumably caused by abrasion during transport. As one would expect, olivine dominates the mineral fragment assemblage, although not to as great an extent as in the lapilli phenocryst assemblages. Olivine tends to form the largest fragments, and its lack of cleavage results in it commonly having irregular shapes. Plagioclase and clinopyroxene are also common as mineral fragments. Plagioclase appears most often as stubby grains, rather than the long prismatic crystals common in the lapilli. Like plagioclase, clinopyroxene tends to form short, stubby prisms, sometimes with rounded corners.

A few samples have clusters of mineral fragments, 1 to $3 \mathrm{~mm}$ in diameter, made up mostly of small plagioclase and clinopyroxene grains $(0.03-0.2 \mathrm{~mm})$ and scattered olivine grains $(0.2-0.5 \mathrm{~mm})$. These clusters are cemented together with green or brown clay minerals. The clusters can be distinguished from lithic fragments (basalt) by the absence of a normal groundmass texture and the fact that most of the grains in these clusters are anhedral, with broken or rounded edges.

Lithic fragments are rarely present in the volcanogenic sediments. When they do occur, they are usually less than $5 \mathrm{~mm}$ across and so intensely altered that everything but a few plagioclase laths in the groundmass has been replaced by secondary minerals.

Zeolite minerals form the matrix of all of the hyaloclastites, cementing the hyaloclasts, mineral, and lithic fragments together. Zeolite makes up 10 to $35 \mathrm{vol} \%$ of the hyaloclastites.

\section{Alteration Effects}

All of the volcaniclastics, both clasts and hyaloclastites, visibly show the effects of seawater alteration. In the clasts, the most widespread alteration effects are the devitrification of glass and the filling of vesicles by smectite and zeolite. Groundmass and phenocryst phases, however, have been largely preserved. Olivine has remained fully or partially intact in two of the five originally olivine-bearing 

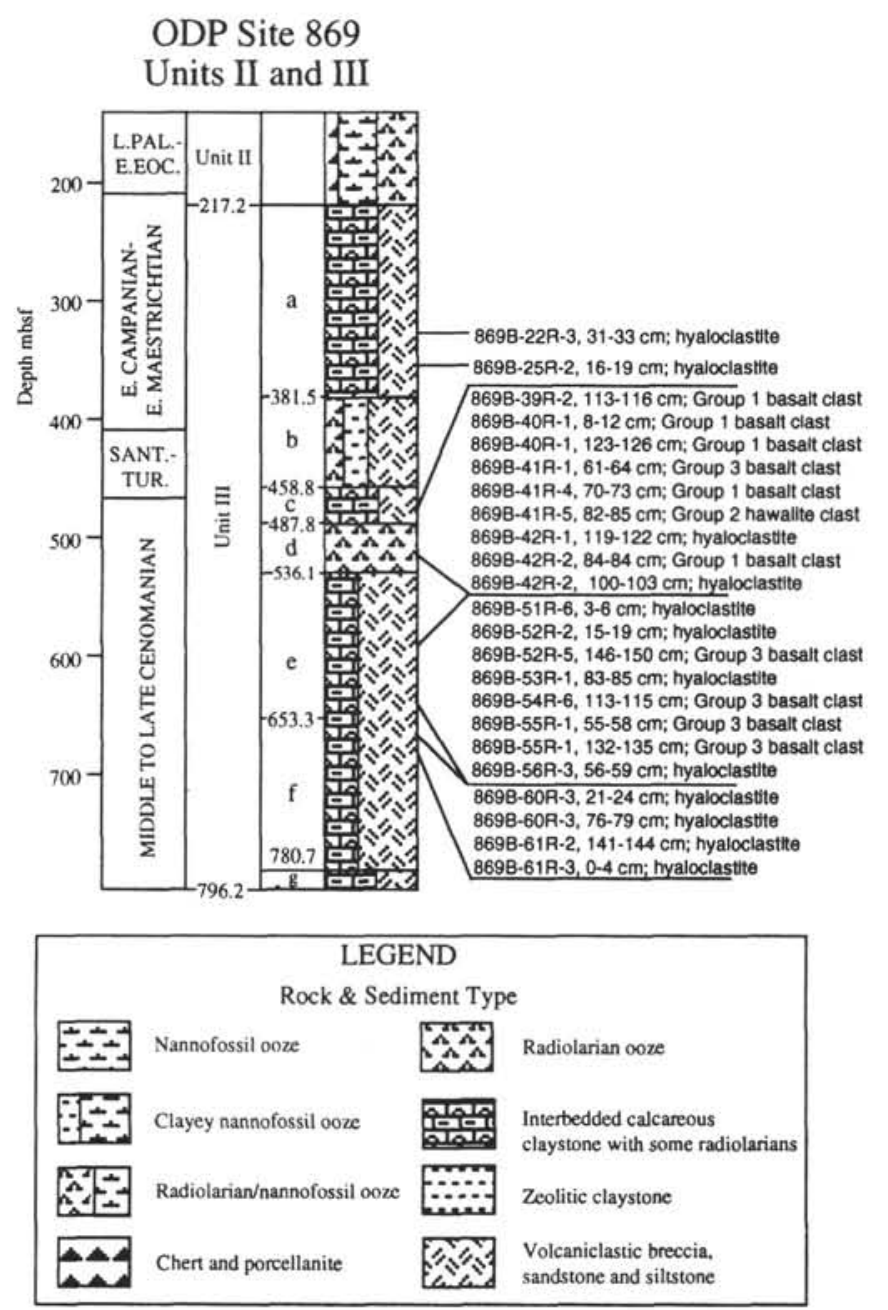

Figure 2. Lithologic column of Units II and III of Site 869, showing the stratigraphic positions and petrographic designation of the lava clasts and hyaloclastites.

clasts, and plagioclase and clinopyroxene, as phenocrysts or groundmass phases, have only been significantly altered in one clast (Sample 143-869B-41R-6, 84-86 cm).

The main effects of alteration visible in the hyaloclastites are the hydration and palagonitization of the glass shards, and the rare filling of vesicles in the glass shards with smectite and zeolite. The phenocrysts and mineral fragments in the hyaloclastites, including the olivine grains, are almost entirely pristine. Overall, the Site 869 samples appear to be slightly less weathered than lavas dredged from seamounts of similar age (e.g., Natland et al., unpubl. data; Davis et al., 1989). The relative lack of alteration probably results from rapid transport and deposition, which would have quickly removed the rocks from unrestricted contact with seawater following eruption. The presence of pristine olivine (which is highly susceptible to alteration, e.g., Staudigel and Hart, 1983) in the hyaloclastites and clasts strongly suggests that they were in contact with seawater for only a short time before being sealed.

\section{ANALYTICAL TECHNIQUES}

Analyses of major elements and $\mathrm{Ba}, \mathrm{Rb}, \mathrm{Sr}, \mathrm{Zr}, \mathrm{Y}, \mathrm{Nb}, \mathrm{V}, \mathrm{Cr}$, and $\mathrm{Ni}$ were performed using $\mathrm{X}$-ray fluorescence (XRF) spectrometry. The major elements were acquired on a Phillips Electronic Instruments AXS-1420 single-channel unit run at $40 \mathrm{~mA}$ and $50 \mathrm{kV}$, using fused glass disks (rock: $\mathrm{LiBO}_{3}=1: 5$ ), following the method of Norrish and
Hutton (1969). The trace elements were acquired on an Applied Research Laboratories 8410 single-channel unit run at $40 \mathrm{~mA}$ and 50 $\mathrm{kV}$, using pressed pellets (rock:cellulose $=3: 1$ ), following the method of Clague (1974). Standardization for major and trace element analysis was conducted using 15 international rock standards, including BCR-1.

Mineral analyses were conducted with two instruments, a Cameca CAMEBAX microprobe and a Cameca SX-50 microprobe, both equipped with wavelength dispersive spectrometers (used for analysis) and energy dispersive systems (used for phase identification). Corrections for interelemental effects (Reed, 1975) were performed using Cameca proprietary software. A 1- to 5- $\mu \mathrm{m}$ beam with an accelerating voltage of $15 \mathrm{kV}$ and beam current of 10 to $15 \mathrm{nA}$ (depending on the phases analyzed) was used for the analyses. Standardization was conducted on a set of 8 to 12 mineral standards at least twice per analysis session.

Rare earth element (REE) determinations were performed on a VG Instruments PlasmaQuad II+ inductively coupled plasma-mass spectrometer (ICP-MS). Multiplier voltage was set at $5 \mathrm{kV}$ and nebulizing gas flow rate at $0.2 \mathrm{lpm}$. ${ }^{115} \mathrm{In}$ was used as an internal standard, and calibration was conducted using standard solutions of 5, 10, 50, and $100 \mathrm{ppb}$ REE. Accuracy and precision of the analyses were monitored using the rock standard AGV-1. Prior to analysis, rock powders ("0.014 g) were dissolved in clean teflon vessels using " $1 \mathrm{~mL}$ of a $2: 1$ mixture of concentrated $\mathrm{HF}$ and $\mathrm{HNO}_{3}$ and heated on a hotplate at low power for 16 to $24 \mathrm{hr}$. The resulting solution was evaporated to dryness, resuspended in a small amount of concentrated $\mathrm{HNO}_{3}$, evaporated to dryness again, and finally diluted to a factor of 1000 in a $1 \%$ $\mathrm{HNO}_{3}$ solution containing $100 \mathrm{ppb}{ }^{115} \mathrm{In}$.

\section{MINERALOGICAL AND GLASS ANALYSES}

Electron micro-analyses were conducted on olivine, clinopyroxene, plagioclase, spinel and glass in Site 869 basalts and hyaloclastites. The compositions of phases from both basalts and hyaloclastites plot as a group on most diagrams, with few observable differences between the two sample types, other than those caused by differing degrees of fractionation. Therefore, we will combine our mineralogical data from the basalts and hyaloclastites and discuss each phase individually.

\section{Olivine}

The olivine grains analyzed are phenocrysts from one Group 1 basalt (Sample 143-869B-41R-4, 70-73 cm, the only basalt in which they were well preserved) and phenocrysts and mineral fragments from 5 hyaloclastites. Representative analyses are presented in Table 2. Olivine compositions range from $\mathrm{Fo}_{64}$ to $\mathrm{Fo}_{89}$ and have an overall mean of $\mathrm{Fo}_{80}$ for 56 analyses. The olivine compositions for the basalt and hyaloclastites overlap, with the only significant differences being the narrow intra-sample compositional range of olivines in the basalt and their slightly lower mean forsterite content $\left(\mathrm{Fo}_{78} \mathrm{vs}\right.$. $\mathrm{Fo}_{81}$ for the hyaloclastites). Olivine core-rim variations are small in the basalt (cores exceed rims by $<0.5 \mathrm{~mol} \% \mathrm{Fo}$ ) and are larger in the hyaloclastites (cores exceed rims by about $1 \mathrm{~mol} \%$ Fo).

The wide range of forsterite contents within several of the hyaloclastite samples (olivine grains in Sample 143-869B-61R-3, 0-4 cm, for example, vary from $\mathrm{Fo}_{64}$ to $\mathrm{Fo}_{85}$ ) suggests that they are the product of more than one flow, or are collections of fragments from a number of variably differentiated lavas.

\section{Clinopyroxene}

Seventy-three analyses of clinopyroxene phenocrysts and groundmass grains were conducted on five clasts and five hyaloclastites from Site 869 (see Table 3 for representative analyses). The clinopyroxenes have moderate to high $\mathrm{Ca}$ contents (wollastonite component 
Table 1. Modes and ages of lava clasts from Site 869.

\begin{tabular}{|c|c|c|c|c|c|c|c|c|c|c|c|}
\hline \multirow[b]{2}{*}{$\begin{array}{l}\text { Core, section, } \\
\text { interval }(\mathrm{cm})\end{array}$} & \multirow[b]{2}{*}{$\begin{array}{l}\text { Petrographic } \\
\text { group }\end{array}$} & \multicolumn{4}{|c|}{ Phenocrysts and microphenocrysts } & \multicolumn{4}{|c|}{ Groundmass } & \multirow[b]{2}{*}{ Vesicularity } & \multirow[b]{2}{*}{$\begin{array}{l}\text { Age } \\
(\mathrm{Ma})^{\mathrm{b}}\end{array}$} \\
\hline & & Plag & $\mathrm{Ol}$ & Cpx & $\mathrm{Hb}$ & Plag & Cpx & Opaques & Matrix ${ }^{\mathrm{a}}$ & & \\
\hline \multicolumn{12}{|l|}{ 143-869B- } \\
\hline $39 \mathrm{R}-2,113-116$ & Group 1 & 1 & 3 & $<1$ & & 48 & 8 & $<1$ & 15 & 25 & \\
\hline $40 \mathrm{R}-1,8-12$ & Group 1 & 2 & 3 & 2 & & 30 & & $<1$ & 62 & 1 & \\
\hline $40 \mathrm{R}-1,123-126$ & Group 1 & 5 & 6 & 1 & & 30 & 5 & $<1$ & 43 & 10 & \\
\hline $41 \mathrm{R}-1,61-64$ & Group 3 & 2 & & 2 & & 42 & 18 & $<1$ & 31 & 5 & \\
\hline $41 R-4,70-73$ & Group 1 & 10 & 4 & 1 & & 25 & 3 & $<1$ & 57 & 0 & $93.5 \pm 1.0$ \\
\hline $41 \mathrm{R}-5,82-85$ & Group 2 & 7 & & 2 & $<1$ & 32 & $<1$ & 2 & 57 & 0 & $96.3 \pm 0.7$ \\
\hline $42 \mathrm{R}-2,84-86$ & Group 1 & 5 & 3 & 3 & & 35 & 3 & $<1$ & 51 & 0 & $94.0 \pm 0.4$ \\
\hline $54 \mathrm{R}-6,113-115$ & Group 3 & 2 & & $<1$ & & 60 & 10 & $<1$ & 20 & 8 & \\
\hline $55 \mathrm{R}-1,55-58$ & Group 3 & 8 & & $<1$ & & 70 & & $<1$ & 22 & ${ }_{0}^{\circ}$ & \\
\hline $55 \mathrm{R}-1,132-135$ & Group 3 & 2 & & $<1$ & & 52 & 7 & $<1$ & 24 & 15 & \\
\hline
\end{tabular}

${ }^{\text {a }}$ Matrix includes fine grained minerals $(<0.01 \mathrm{~mm})$ and altered glass.

${ }^{b}$ Age data are from Pringle and Duncan (this volume).

Notes: Plag = plagioclase; $\mathrm{Ol}=$ olivine; $\mathrm{Cpx}=$ clinopyroxene; $\mathrm{Hb}=$ hornblende. Abundances based on visual estimation, and all values given in volume percent. See text for textural descriptions.

Table 2. Representative analyses of olivine phenocrysts from Site 869 lava clasts and hyaloclastites.

\begin{tabular}{|c|c|c|c|c|c|c|c|c|c|}
\hline $\begin{array}{l}\text { Hole: } \\
\text { Core, section: } \\
\text { Interval }(\mathrm{cm}) \text { : } \\
\text { Rock type: }\end{array}$ & $\begin{array}{c}869 \mathrm{~B} \\
41 \mathrm{R}-4 \\
70-73 \\
\text { Group } 1\end{array}$ & $\begin{array}{c}869 \mathrm{~B} \\
41 \mathrm{R}-4 \\
70-73 \\
\text { Group } 1\end{array}$ & $\begin{array}{c}869 \mathrm{~B} \\
42 \mathrm{R}-1 \\
119-122 \\
\text { Hyalocl. }\end{array}$ & $\begin{array}{c}869 \mathrm{~B} \\
42 \mathrm{R}-2 \\
100-103 \\
\text { Hyalocl. }\end{array}$ & $\begin{array}{c}869 \mathrm{~B} \\
56-3 \\
56-59 \\
\text { Hyalocl. }\end{array}$ & $\begin{array}{c}\text { 869B } \\
60 \mathrm{R}-3 \\
21-24 \\
\text { Hyalocl. }\end{array}$ & $\begin{array}{c}869 \mathrm{~B} \\
60 \mathrm{R}-3 \\
21-24 \\
\text { Hyalocl. }\end{array}$ & $\begin{array}{c}869 \mathrm{~B} \\
61 \mathrm{R}-3 \\
0-4 \\
\text { Hyaocl. }\end{array}$ & $\begin{array}{c}869 \mathrm{~B} \\
61 \mathrm{R}-3 \\
0-4 \\
\text { Hyalocl. }\end{array}$ \\
\hline $\begin{array}{l}\mathrm{SiO}_{2} \\
\mathrm{TiO}_{2} \\
\mathrm{Al}_{2} \mathrm{O}_{3} \\
\mathrm{FeO} \\
\mathrm{MnO} \\
\mathrm{MgO} \\
\mathrm{CaO} \\
\mathrm{NiO} \\
\mathrm{Sum}\end{array}$ & $\begin{array}{r}38.19 \\
0.00 \\
0.04 \\
20.07 \\
0.31 \\
40.94 \\
0.27 \\
0.14 \\
99.96\end{array}$ & $\begin{array}{r}38.05 \\
0.04 \\
0.04 \\
20.13 \\
0.27 \\
40.90 \\
0.27 \\
0.15 \\
99.96\end{array}$ & $\begin{array}{r}39.19 \\
0.01 \\
0.06 \\
16.49 \\
0.24 \\
43.37 \\
0.38 \\
0.26 \\
100.07\end{array}$ & $\begin{array}{r}39.14 \\
0.05 \\
0.24 \\
16.83 \\
0.25 \\
43.16 \\
0.41 \\
0.17 \\
100.34\end{array}$ & $\begin{array}{r}38.88 \\
0.06 \\
0.07 \\
16.78 \\
0.21 \\
42.56 \\
0.38 \\
0.23 \\
99.30\end{array}$ & $\begin{array}{r}38.47 \\
0.03 \\
0.01 \\
22.74 \\
0.26 \\
37.36 \\
0.36 \\
0.16 \\
99.39\end{array}$ & $\begin{array}{r}40.15 \\
0.02 \\
0.07 \\
15.69 \\
0.33 \\
43.09 \\
0.25 \\
0.36 \\
99.96\end{array}$ & $\begin{array}{r}39.09 \\
0.03 \\
0.05 \\
18.56 \\
0.36 \\
41.58 \\
0.33 \\
0.25 \\
100.25\end{array}$ & $\begin{array}{c}37.02 \\
0.04 \\
0.01 \\
30.61 \\
0.52 \\
31.53 \\
0.36 \\
0 \\
100.25\end{array}$ \\
\hline $\begin{array}{l}\text { Cations/4 Oxy } \\
\mathrm{Si} \\
\mathrm{Ti} \\
\mathrm{Al} \\
\mathrm{Fe} \\
\mathrm{Mn} \\
\mathrm{Mg} \\
\mathrm{Ca} \\
\mathrm{Sum} \\
\mathrm{Fo}\end{array}$ & $\begin{array}{c}0.99 \\
0.00 \\
0.00 \\
0.43 \\
0.01 \\
1.57 \\
0.01 \\
3.01 \\
78.2 \%\end{array}$ & $\begin{array}{c}0.98 \\
0.00 \\
0.00 \\
0.44 \\
0.01 \\
1.58 \\
0.01 \\
3.01 \\
78.1 \%\end{array}$ & $\begin{array}{r}0.99 \\
0.00 \\
0.00 \\
0.35 \\
0.01 \\
1.64 \\
0.01 \\
3.00 \\
82.2 \%\end{array}$ & $\begin{array}{l}0.99 \\
0.00 \\
0.01 \\
0.36 \\
0.01 \\
1.63 \\
0.01 \\
3.00 \\
81.8 \%\end{array}$ & $\begin{array}{r}0.99 \\
0.00 \\
0.00 \\
0.36 \\
0.00 \\
1.62 \\
0.01 \\
3.00 \\
81.7 \%\end{array}$ & $\begin{array}{c}1.01 \\
0.00 \\
0.00 \\
0.50 \\
0.01 \\
1.46 \\
0.01 \\
2.99 \\
74.3 \%\end{array}$ & $\begin{array}{l}1.01 \\
0.00 \\
0.00 \\
0.33 \\
0.01 \\
1.62 \\
0.01 \\
2.98 \\
82.7 \%\end{array}$ & $\begin{array}{l}1.00 \\
0.00 \\
0.00 \\
0.40 \\
0.01 \\
1.58 \\
0.01 \\
3.00 \\
79.7 \%\end{array}$ & $\begin{array}{l}1.00 \\
0.00 \\
0.00 \\
0.69 \\
0.01 \\
1.27 \\
0.01 \\
2.99 \\
64.3 \%\end{array}$ \\
\hline
\end{tabular}

ranges from $39.7 \%$ to $45.4 \%$ ) and wide ranges of $\mathrm{Al}_{2} \mathrm{O}_{3}(1.75-6.22$ $\mathrm{wt} \%), \mathrm{TiO}_{2}(0.72-2.64 \mathrm{wt} \%)$ and $\mathrm{Mg} \#(\mathrm{Mg} /(\mathrm{Mg}+\mathrm{Fe})=0.74-0.85)$.

The clinopyroxene data form a tight group on the pyroxene quadrilateral around the diopside-salite-endiopside-augite junction (at $\mathrm{Wo}_{45}, \mathrm{En}_{45}$ ), plotting in all four fields (Fig. 3). They also form a well-defined fractionation trend on a diagram of weight percent $\mathrm{TiO}_{2}$ vs. Mg\# (Fig. 4A). Clinopyroxenes from lavas on the summit of Wodejebato, sampled at Sites 873 through 877 show a similar trend, although with a greater range of $\mathrm{Mg} \#$ and $\mathrm{TiO}_{2}$ values (Dieu, in press).

On a plot of $\mathrm{Al}(\mathrm{z})$ (\% $\mathrm{Al}$ in tetrahedral site) vs. $\mathrm{TiO}_{2}$ (Fig. 4B.), the clinopyroxene data form a single array, divided about equally between the subalkaline and alkaline fields (Fig. 3B). The array appears to represent a fractionation trend, as the clinopyroxene compositions with the lowest $\mathrm{TiO}_{2}$ and $\mathrm{Al}(\mathrm{z})$ values have the highest Mg\# (Fig. 4A), and thus the clinopyroxenes plotting in the subalkaline field probably indicate crystallization from extremely mafic, rather than tholeiitic, liquids. This argument is supported by the fact that all of the Site 869 clinopyroxenes have greater abundances of tetrahedral aluminum $\left(\mathrm{Al}^{\mathrm{IV}}\right)$ than of octahedral aluminum $\left(\mathrm{Al}^{\mathrm{VI}}\right.$; Fig. $\left.4 \mathrm{C}\right)$, which is characteristic of clinopyroxenes from alkalic lavas (Le Bas, 1962).

Despite considerable overlap, some consistent variations in clinopyroxene composition are observed between the lavas of Groups 1, 2 , and 3. Group 1 lavas have the smallest range of clinopyroxene compositions and have the lowest average $\mathrm{TiO}_{2} \mathrm{wt} \%, \mathrm{Al}_{2} \mathrm{O}_{3}$, and

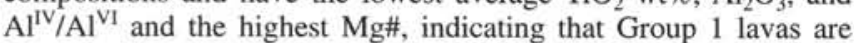
among the most mafic. Group 2 clinopyroxene grains have the high-

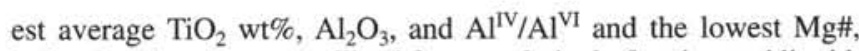
indicating that they crystallized from a relatively fractionated liquid. Both the clinopyroxene grains from the Group 3 lavas and the hyaloclastites span wide compositional ranges, suggesting that they crystallized from a series of variably fractionated melts.

\section{Plagioclase}

Site 869 plagioclase compositions range from bytownite to andesine $\left(\mathrm{An}_{74}-\mathrm{An}_{40}\right.$; Table 4, Fig. 5). Group 1 lavas have the most calcic $\left(\mathrm{An}_{74-55}\right)$ phenocrysts, and those of Group 2 have the least $\left(\mathrm{An}_{59-40}\right)$. Hyaloclastite plagioclase compositions show relatively little variation and fall between $\mathrm{An}_{60}$ and $\mathrm{An}_{70}$. Core-rim variations for plagioclase phenocrysts can be high, with cores having up to $6-10 \mathrm{~mol} \%$ more anorthite than the rims, particularly in the Group 2 lava. The K contents of the plagioclase grains are typical of mafic to moderately fractionated alkalic ocean island lavas (Basaltic Volcanism Study Project, 1981) with the lowest values, $0.8-1.5 \mathrm{~mol} \%$ orthoclase (Or), in the Group 1 basalts and the highest values ( $1.5 \%-3.7 \%$ Or) in the Group 2 hawaiite.

\section{Oxide Minerals}

Oxide minerals in Site 869 basalts and hyaloclastites consist of $\mathrm{Cr}$-spinel, most often found with olivine, and $\mathrm{Fe}-\mathrm{Ti}$ oxide minerals. The $\mathrm{Cr}$-spinel has $\mathrm{Cr}$ numbers $[\mathrm{Cr} /(\mathrm{Cr}+\mathrm{Al})], \mathrm{Mg} \#$, and $\mathrm{TiO}_{2}$ values typical of ocean island basalts (Sen and Presnall, 1986). The Fe-Ti 
Table 3. Representative clinopyroxene and hornblende analyses from Site 869 basalts and hyaloclastites.

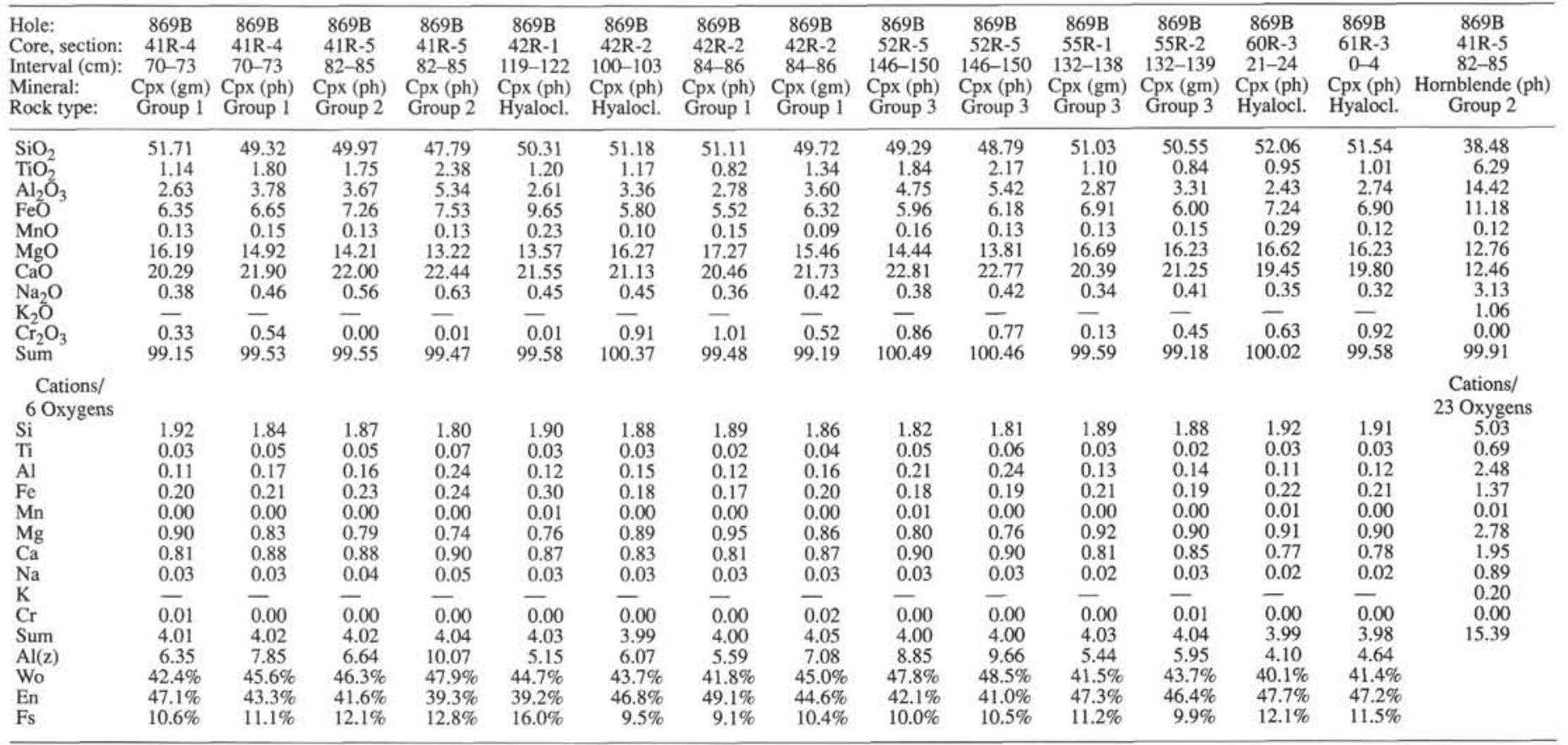

Note: The suffixes (ph) and (gm) refer to phenocryst and groundmass clinopyroxenes, respectively.

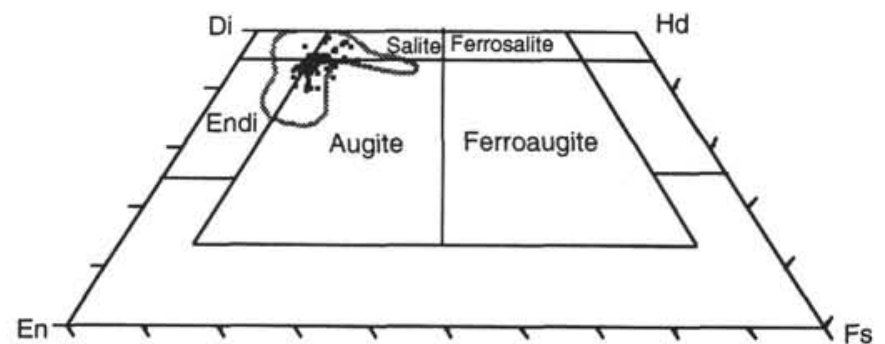

Figure 3. Clinopyroxene quadrilateral, showing the compositions of clinopyroxene grains from Site 869 lava clasts and hyaloclastites. Compositions of clinopyroxene phenocrysts from the island of Hawaii are shown in the field outlined in gray (Basaltic Volcanism Study Project [BVSP], 1981).

oxide minerals are normally present as small $(0.01-0.05 \mathrm{~mm})$ euhedral grains in the basalts, suggesting that they are primary phases, not the products of oxidative alteration.

\section{Glass}

Approximately 30 shards of glass from three hyaloclastite samples were analyzed by microprobe. All analyses of the glasses have extremely low totals $(78 \%-90 \%)$, presumably because of high volatile contents from palagonitization. Because seawater alteration of basaltic glass commonly changes the abundances of several elements, particularly the alkalis Na and K (Mottl and Holland, 1978; Verma, 1992), these glass compositions are of little use for determining original melt compositions or extents of fractionation.

The only glass analyzed that has a negligible water content is a glass inclusion in an olivine phenocryst (from a hyaloclastite: Sample 143$869 \mathrm{~B}-42 \mathrm{R}-2,100-103 \mathrm{~cm}$ ) that has the composition of a hawaiite.

\section{GEOCHEMISTRY OF BASALTIC CLASTS}

Major, trace, and rare-earth element data were collected on the 11 basaltic clasts and on two of the 12 hyaloclastite samples; chemical data are presented in Table 5. The hyaloclastite data are presented only for comparison, as the hydration and alteration of the glass and the large amount of zeolite matrix make these samples of limited use for chemical characterization.

\section{Major Element Chemistry}

All of the Site 869 clasts have been moderately to strongly altered, as is shown by their moderate to high loss-on-ignition (LOI) values (1.7-7.1 wt \%; $4.4 \mathrm{wt} \%$ average). Seawater alteration commonly changes the major-element composition of basalts to a large degree (e.g., Alt and Emmermann, 1985; Alt et al., 1986), and the elements K and $\mathrm{Na}$ are particularly susceptible to mobilization (Mottl and Holland, 1978; Verma, 1992). Therefore, classification of the clasts using standard major-element discrimination diagrams, such as silica vs. total alkalis, is not a reliable method for determining their petrologic affinity. Nevertheless, we note that the four least-altered clasts (two from Group 1, one from Group 2 and one from Group 3, all having LOI of $3.13 \mathrm{wt} \%$ ) fall within the alkalic field of MacDonald and Katsura (1964), based on their volatile-free $\mathrm{SiO}_{2}, \mathrm{Na}_{2} \mathrm{O}$, and $\mathrm{K}_{2} \mathrm{O}$ contents.

\section{Trace Element Chemistry}

In addition to the major elements, interaction with seawater is widely known to change the concentration of many trace elements in basalts (e.g., Hart et al., 1974; Verma, 1992). However, certain elements, such as the high-field-strength elements (HFSE; including Nb, $\mathrm{Zr}, \mathrm{Y}, \mathrm{Ti}$ and others), have been shown to be highly resistant to mobilization by seawater (e.g., Cann, 1970; Pearce and Cann, 1973; Hart et al., 1974; Bienvenu et al., 1990). Similarly, certain ratios of rare-earth element (REE) abundances also are not appreciably changed by interaction with seawater (Staudigel and Hart, 1983; Bienvenu et al., 1990). Based on this evidence, we will primarily rely on the HFSE and REE data to characterize the geochemistry of the clasts.

The Site 869 clasts have moderate to high, incompatible traceelement concentrations and ratios of highly to moderately incompatible trace elements $(\mathrm{H} / \mathrm{M}$ ratios, such as $\mathrm{Zr} / \mathrm{Y}$ and $\mathrm{La} / \mathrm{Sm})$. All of the clasts have $\mathrm{Nb} / \mathrm{Y}$ ratios greater than 1 , which is typical of alkalic 
basalts (Winchester and Floyd, 1976). The clasts are also moderately to strongly enriched in the light REE (Fig. 6; [La/Sm]N ranges from 2.0 to 4.5). In the Zr-Ti-Y ternary diagram of Pearce and Cann (1973; Fig. 7), all but one of the Site 869 clasts fall in the field for intraplate basalts. The one exception is the fractionated Group 2 hawaiite, which plots toward the high $\mathrm{Zr}$ end of the diagram. In all these respects, the Site 869 clasts resemble typical alkalic OIB.

On incompatible element vs. incompatible element and incompatible element vs. H/M ratio diagrams (Figs. 8 and 9), the Site 869 clasts form inclined linear arrays, with the Group 3 basalts having the lowest incompatible element contents and ratios, the Group 1 basalts in the middle, and the Group 3 hawaiite having by far the highest incompatible element concentration and ratio values.

\section{DISCUSSION}

\section{Petrogenesis}

The mineral compositions and immobile incompatible traceelement contents and ratios of the Site 869 clasts indicate that they are mildly to moderately alkalic lavas. The Group 2 hawaiite clast appears to be more alkalic than the others based on its high incompatible element concentrations (Figs. 8 and 9). Although the incompatible element contents of the hawaiite may have been increased by fractionation, its $\mathrm{Zr} / \mathrm{Y}$ and $\mathrm{La} / \mathrm{Sm}$ ratios (which are $35 \%-40 \%$ higher than those of any other clast) probably are more representative of source composition and melting conditions than extreme crystal fractionation. It is also unlikely that fractionation was the controlling factor in the incompatible element contents of the other lavas, because the Group 1 clasts, which are the most mafic (based on their mineral compositions), have higher incompatible element concentrations and $\mathrm{H} / \mathrm{M}$ ratios than the variably fractionated Group 3 clasts.

In trace element vs. trace element ratio diagrams (such as Fig. 9), sloping linear arrays are normally formed by lavas produced by different degrees of partial melting, because ratios of highly to moderately incompatible elements are strongly affected by variations in degree of partial melting, but not by small to moderate degrees of fractional crystallization (e.g., Allegré et al., 1977; Minster and Allegré, 1978). A mantle source containing garnet in the residue, for example, would preferentially retain $\mathrm{Y}$ and the heavier REE and could produce melts having a wide range of $\mathrm{Zr} / \mathrm{Y}$ and $\mathrm{La} / \mathrm{Sm}$ ratios by only slightly varying the degree of melting. Therefore, the sloped linear arrays in Figure 9 appear to indicate that the Site 869 clasts are the result of a series of melts produced by varying degrees of equilibrium partial melting of a homogeneous, incompatible element-enriched mantle source (Minster and Allegré, 1978; Pearce and Norry, 1979); the Group 3 lavas being produced by the largest degrees of melting and the Group 2 lava produced by the smallest. However, the wide ranges of $\mathrm{Sr}, \mathrm{Nd}$, and $\mathrm{Pb}$ isotope ratios and incompatible element ratios, particularly $\mathrm{Nb} / \mathrm{Zr}$ and $\mathrm{La} / \mathrm{Nb}$, argue against 5a homogeneous mantle source (see "Mantle Source Composition" section, this chapter, below). Therefore, it is more likely that the clasts are the products both of mixing and various degrees of melting of at least two distinct mantle end-components, each having moderate to high concentrations of incompatible trace elements relative to the MORB source mantle.

Subsequent to melting, the liquids underwent small to moderate degrees of crystal fractionation. Olivine and $\mathrm{Cr}$-spinel appear to have been the most important early fractionating phases, indicated by the wide intragroup ranges of $\mathrm{Ni}$ and $\mathrm{Cr}$ values in the basalts (Fig. 10). Clinopyroxene, however, does not appear to have been a significant member of the early fractionating assemblage, as the basalts do not show negative correlations between $\mathrm{Cr}$ content and $\mathrm{Zr} / \mathrm{Y}$ ratios. Clinopyroxene preferentially incorporates $\mathrm{Y}$ over $\mathrm{Zr}$ (Pearce and Norry, 1979; Hart and Dunn, 1993) and, thus, fractionation of clinopyroxene should result in increasing $\mathrm{Zr} / \mathrm{Y}$ ratios, with decreasing $\mathrm{Cr}$ concentrations. Fractionation of clinopyroxene probably became important at a later stage than that of olivine and spinel. Other late-stage fractionating phases may have included $\mathrm{Fe}-\mathrm{Ti}$ oxides and/or horn-
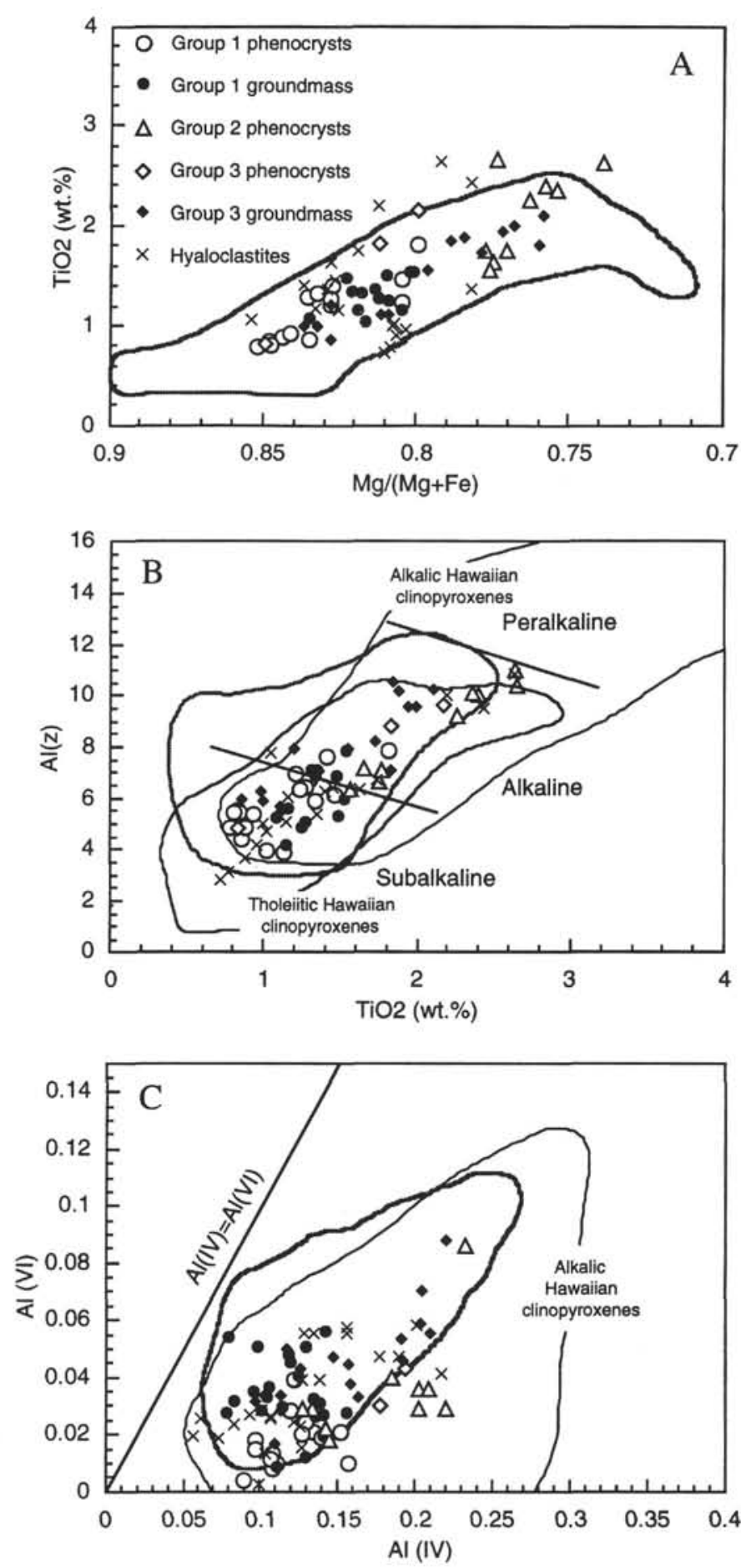

Figure 4. A. Mg \# vs. wt $\% \mathrm{TiO}_{2}$ for Site 869 clinopyroxene phenocrysts and groundmass grains. $\mathrm{B}$. $\mathrm{TiO}_{2}$ wt $\%$ vs. $\mathrm{Al}(\mathrm{z})(\% \mathrm{Al}$ in tetrahedral site) for Site 869 clinopyroxene grains. Subalkaline/alkaline/peralkaline fields from Le Bas (1962). C. $\mathrm{Al}^{\mathrm{IV}}$ vs. $\mathrm{Al}^{\mathrm{VI}}$ (cations/6 oxygens) for Site 869 clinopyroxene grains. Fields for tholeiitic and alkalic Hawaiian clinopyroxene data are from Fodor et al. (1975); Clague et al. (1980); Garcia et al. (1986); Frey et al. (1990), and Chen et al. (1990). Field outlined in gray in all diagrams is for clinopyroxene analyses from Leg 144 Sites $873,874,875,876$, and 877, Wodejebato Guyot (Dieu, in press). 
Table 4. Representative plagioclase analyses from Site 869 basalts and hyaloclastites.

\begin{tabular}{|c|c|c|c|c|c|c|c|c|c|c|c|c|}
\hline $\begin{array}{l}\text { Hole: } \\
\text { Core, section: } \\
\text { Interval }(\mathrm{cm}) \text { : } \\
\text { Rock type: }\end{array}$ & $\begin{array}{c}869 \mathrm{~B} \\
41 \mathrm{R}-4 \\
70-73 \\
\text { Group 1 } \\
\text { Pheno }\end{array}$ & $\begin{array}{c}\text { 869B } \\
41 R-4 \\
70-73 \\
\text { Group 1 } \\
\text { Pheno }\end{array}$ & $\begin{array}{c}869 \mathrm{~B} \\
41 \mathrm{R}-4 \\
70-73 \\
\text { Group 1 } \\
\text { Pheno }\end{array}$ & $\begin{array}{c}\text { 869B } \\
41 \mathrm{R}-5 \\
82-85 \\
\text { Group 2 } \\
\text { Pheno }\end{array}$ & $\begin{array}{c}869 \mathrm{~B} \\
41 \mathrm{R}-5 \\
82-85 \\
\text { Group 2 } \\
\text { Gm }\end{array}$ & $\begin{array}{c}869 \mathrm{~B} \\
41 \mathrm{R}-5 \\
82-85 \\
\text { Group 2 } \\
\text { Gm }\end{array}$ & $\begin{array}{c}\text { 869B } \\
42 \mathrm{R}-1 \\
119-122 \\
\text { hyalocl. } \\
\text { Pheno }\end{array}$ & $\begin{array}{c}\text { 869B } \\
42 \mathrm{R}-2 \\
84-86 \\
\text { Group 1 } \\
\text { Pheno }\end{array}$ & $\begin{array}{c}\text { 869B } \\
42 \mathrm{R}-2 \\
84-86 \\
\text { Group 1 } \\
\text { Pheno }\end{array}$ & $\begin{array}{c}\text { 869B } \\
42 \mathrm{R}-2 \\
84-86 \\
\text { Group 1 } \\
\text { Pheno }\end{array}$ & $\begin{array}{c}\text { 869B } \\
42 \mathrm{R}-2 \\
100-103 \\
\text { Hyalocl. } \\
\text { Pheno }\end{array}$ & $\begin{array}{c}869 \mathrm{~B} \\
56 \mathrm{R}-3 \\
56-59 \\
\text { Hyalocl. } \\
\text { Pheno }\end{array}$ \\
\hline $\begin{array}{l}\mathrm{SiO}_{2} \\
\mathrm{TiO}_{2} \\
\mathrm{Al}_{2} \mathrm{O}_{3} \\
\mathrm{FeO} \\
\mathrm{MnO} \\
\mathrm{MgO} \\
\mathrm{CaO} \\
\mathrm{Na}_{2} \mathrm{O} \\
\mathrm{K}_{2} \mathrm{O} \\
\mathrm{Sum}\end{array}$ & $\begin{array}{r}49.35 \\
0.10 \\
31.62 \\
0.63 \\
0.01 \\
0.09 \\
14.15 \\
3.36 \\
0.12 \\
99.48\end{array}$ & $\begin{array}{r}50.96 \\
0.08 \\
29.83 \\
0.61 \\
0.02 \\
0.16 \\
13.48 \\
4.32 \\
0.22 \\
99.71\end{array}$ & $\begin{array}{r}49.65 \\
0.18 \\
31.26 \\
0.52 \\
0.01 \\
0.11 \\
14.56 \\
3.52 \\
0.17 \\
99.98\end{array}$ & $\begin{array}{r}52.50 \\
0.12 \\
29.50 \\
0.50 \\
0.03 \\
0.06 \\
12.06 \\
5.17 \\
0.26 \\
100.22\end{array}$ & $\begin{array}{r}53.32 \\
0.12 \\
28.56 \\
0.50 \\
0.01 \\
0.04 \\
11.02 \\
5.58 \\
0.35 \\
99.53\end{array}$ & $\begin{array}{r}54.86 \\
0.11 \\
27.84 \\
0.90 \\
0.01 \\
0.22 \\
8.87 \\
5.92 \\
0.52 \\
99.25\end{array}$ & $\begin{array}{r}50.45 \\
0.07 \\
30.51 \\
0.47 \\
0.02 \\
0.14 \\
13.96 \\
3.87 \\
0.12 \\
99.66\end{array}$ & $\begin{array}{r}50.42 \\
0.10 \\
30.65 \\
0.50 \\
0.03 \\
0.13 \\
13.77 \\
4.00 \\
0.19 \\
99.87\end{array}$ & $\begin{array}{r}49.54 \\
0.11 \\
31.44 \\
0.52 \\
0.01 \\
0.13 \\
14.34 \\
3.65 \\
0.18 \\
100.02\end{array}$ & $\begin{array}{r}50.99 \\
0.12 \\
30.35 \\
0.42 \\
0.01 \\
0.14 \\
13.68 \\
4.20 \\
0.21 \\
100.15\end{array}$ & $\begin{array}{r}51.58 \\
0.10 \\
30.03 \\
0.47 \\
0.01 \\
0.06 \\
13.21 \\
4.30 \\
0.26 \\
100.02\end{array}$ & $\begin{array}{r}51.73 \\
0.08 \\
28.66 \\
0.36 \\
0.03 \\
0.19 \\
14.05 \\
4.57 \\
0.14 \\
99.81\end{array}$ \\
\hline $\begin{array}{l}\text { Cations/8 oxy } \\
\mathrm{Si} \\
\mathrm{Ti} \\
\mathrm{Al} \\
\mathrm{Fe} \\
\mathrm{Mn} \\
\mathrm{Mg} \\
\mathrm{Ca} \\
\mathrm{Na} \\
\mathrm{K} \\
\mathrm{Sum} \\
\mathrm{An} \\
\mathrm{Ab} \\
\mathrm{Or}\end{array}$ & $\begin{array}{c}2.27 \\
0.00 \\
1.71 \\
0.02 \\
0.00 \\
0.01 \\
0.70 \\
0.30 \\
0.01 \\
5.02 \\
69.4 \% \\
29.9 \% \\
0.7 \%\end{array}$ & $\begin{array}{l}2.34 \\
0.00 \\
1.61 \\
0.02 \\
0.00 \\
0.01 \\
0.66 \\
0.38 \\
0.01 \\
5.05 \\
62.5 \% \\
36.3 \% \\
1.2 \%\end{array}$ & $\begin{array}{l}2.28 \\
0.01 \\
1.69 \\
0.02 \\
0.00 \\
0.01 \\
0.71 \\
0.31 \\
0.01 \\
5.03 \\
68.9 \% \\
30.2 \% \\
0.9 \%\end{array}$ & $\begin{array}{r}2.39 \\
0.00 \\
1.58 \\
0.02 \\
0.00 \\
0.00 \\
0.59 \\
0.46 \\
0.01 \\
5.05 \\
55.5 \% \\
43.1 \% \\
1.4 \%\end{array}$ & $\begin{array}{c}2.43 \\
0.00 \\
1.54 \\
0.02 \\
0.00 \\
0.00 \\
0.54 \\
0.49 \\
0.02 \\
5.05 \\
51.2 \% \\
46.9 \% \\
1.9 \%\end{array}$ & $\begin{array}{r}2.43 \\
0.00 \\
1.55 \\
0.02 \\
0.00 \\
0.00 \\
0.51 \\
0.51 \\
0.03 \\
5.06 \\
49.0 \% \\
48.4 \% \\
2.6 \%\end{array}$ & $\begin{array}{l}2.31 \\
0.00 \\
1.65 \\
0.02 \\
0.00 \\
0.01 \\
0.69 \\
0.34 \\
0.01 \\
5.03 \\
66.2 \% \\
33.1 \% \\
0.7 \%\end{array}$ & $\begin{array}{r}2.50 \\
0.00 \\
1.49 \\
0.03 \\
0.00 \\
0.02 \\
0.43 \\
0.52 \\
0.03 \\
5.03 \\
43.9 \% \\
53.0 \% \\
3.1 \%\end{array}$ & $\begin{array}{r}2.27 \\
0.00 \\
1.70 \\
0.02 \\
0.00 \\
0.01 \\
0.70 \\
0.32 \\
0.01 \\
5.04 \\
67.8 \% \\
31.2 \% \\
1.0 \%\end{array}$ & $\begin{array}{r}2.33 \\
0.00 \\
1.63 \\
0.02 \\
0.00 \\
0.01 \\
0.67 \\
0.37 \\
0.01 \\
5.04 \\
63.5 \% \\
35.3 \% \\
1.2 \%\end{array}$ & $\begin{array}{c}2.35 \\
0.00 \\
1.61 \\
0.02 \\
0.00 \\
0.00 \\
0.65 \\
0.38 \\
0.02 \\
5.03 \\
62.0 \% \\
36.5 \% \\
1.5 \%\end{array}$ & $\begin{array}{r}2.37 \\
0.00 \\
1.55 \\
0.01 \\
0.00 \\
0.01 \\
0.69 \\
0.41 \\
0.01 \\
5.06 \\
62.5 \% \\
36.8 \% \\
0.7 \%\end{array}$ \\
\hline
\end{tabular}

Note: Pheno and $\mathrm{Gm}$ refer to phenocryst and groundmass, respectively.

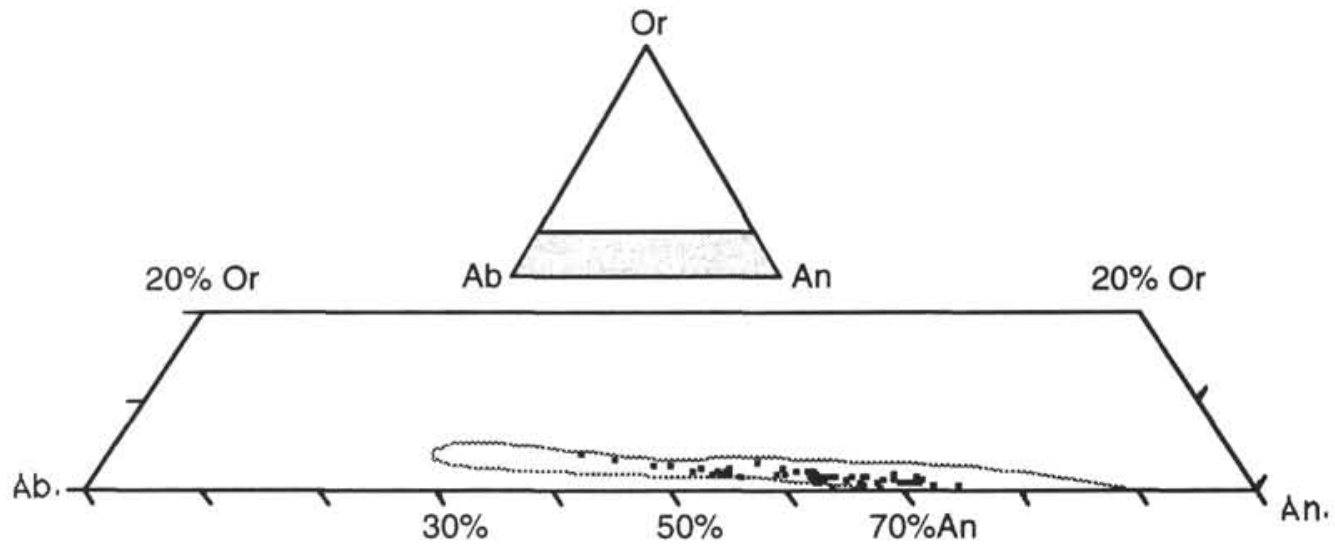

Figure 5. Compositions of Site 869 plagioclase grains. Note the systematic increase in orthoclase with decreasing anorthite. Gray outlined field shows compositions of plagioclase phenocrysts in lavas from the island of Hawaii (BVSP, 1981).

blende, indicated by the low $\mathrm{Ti}$ value in the hawaiite. The moderate positive Eu anomalies in most of the clasts suggest that plagioclase accumulation was common, or that their source was slightly enriched in Eu (e.g., King et al., in press).

\section{Mantle Source Composition}

A simple homogeneous mantle source hypothesis might explain much of the geochemical variation found in the Site 869 lava clasts. Mildly and moderately alkalic lavas can be generated from mantle of the same composition if the depths and degrees of melting are varied (Yoder and Tilley, 1962; Falloon et al., 1988). However, strong evidence exists that the mantle source of the Site 869 clasts was not homogeneous. A number of geochemical tracers change very little, if at all, during melting and fractional crystallization. Isotopes, of course, are the best known of these tracers, but certain ratios of incompatible elements, such as $\mathrm{Nb} / \mathrm{Zr}, \mathrm{La} / \mathrm{Nb}, \mathrm{Ba} / \mathrm{Nb}$, and others, also have been shown to be useful indicators of source mantle composition (Weaver, 1991; le Roex, 1986; Erlank and Kable, 1976). The Nb/Zr and $\mathrm{La} / \mathrm{Nb}$ ratios of the Site 869 clasts are plotted in Figure 11. Both $\mathrm{Nb} / \mathrm{Zr}$ and $\mathrm{La} / \mathrm{Nb}$ values span moderate to large ranges $(\mathrm{Nb} / \mathrm{Zr}=$ $0.20-0.27, \mathrm{La} / \mathrm{Nb}=0.6-0.8)$, greater than the analytical uncertainty for both ratios $(2 \sigma= \pm 10 \%$ for $\mathrm{Nb} / \mathrm{Zr} ; \pm 15 \%$ for $\mathrm{La} / \mathrm{Nb})$. Admittedly, some of the variation in $\mathrm{La} / \mathrm{Nb}$ ratios may result from the effects of secondary alteration, but even the least-altered samples have a considerable range of $\mathrm{La} / \mathrm{Nb}$ values.

The wide ranges of these trace-element ratios in the Site 869 clasts strongly suggest that the mantle material that produced them was heterogeneous. In addition, the range of $\mathrm{Nb} / \mathrm{Zr}$ values in the clasts extends from the high $\mathrm{Nb} / \mathrm{Zr}$ end of the field for Samoan lavas from Tutuila (Dieu, in press) to the low $\mathrm{Nb} / \mathrm{Zr}$ end of the fields for lavas from Mangaia and Tubuai in the Cook-Austral Islands (Palacz and Saunders, 1986; Chauvel et al., 1992; Fig. 11). These three localities are noted for having some of the most extreme trace-element and isotopic compositions found in oceanic basalts (e.g., White and Hofmann, 1982; Palacz and Saunders, 1986) and are identified with two of the four mantle end-member components defined by Zindler and Hart (1986): the Enriched-Mantle II (EMII) component with 
Table 5. Major- and trace-element data for $\mathbf{1 1}$ basaltic clasts and two hyaloclastites extracted from volcaniclastic sediments at Site 869.

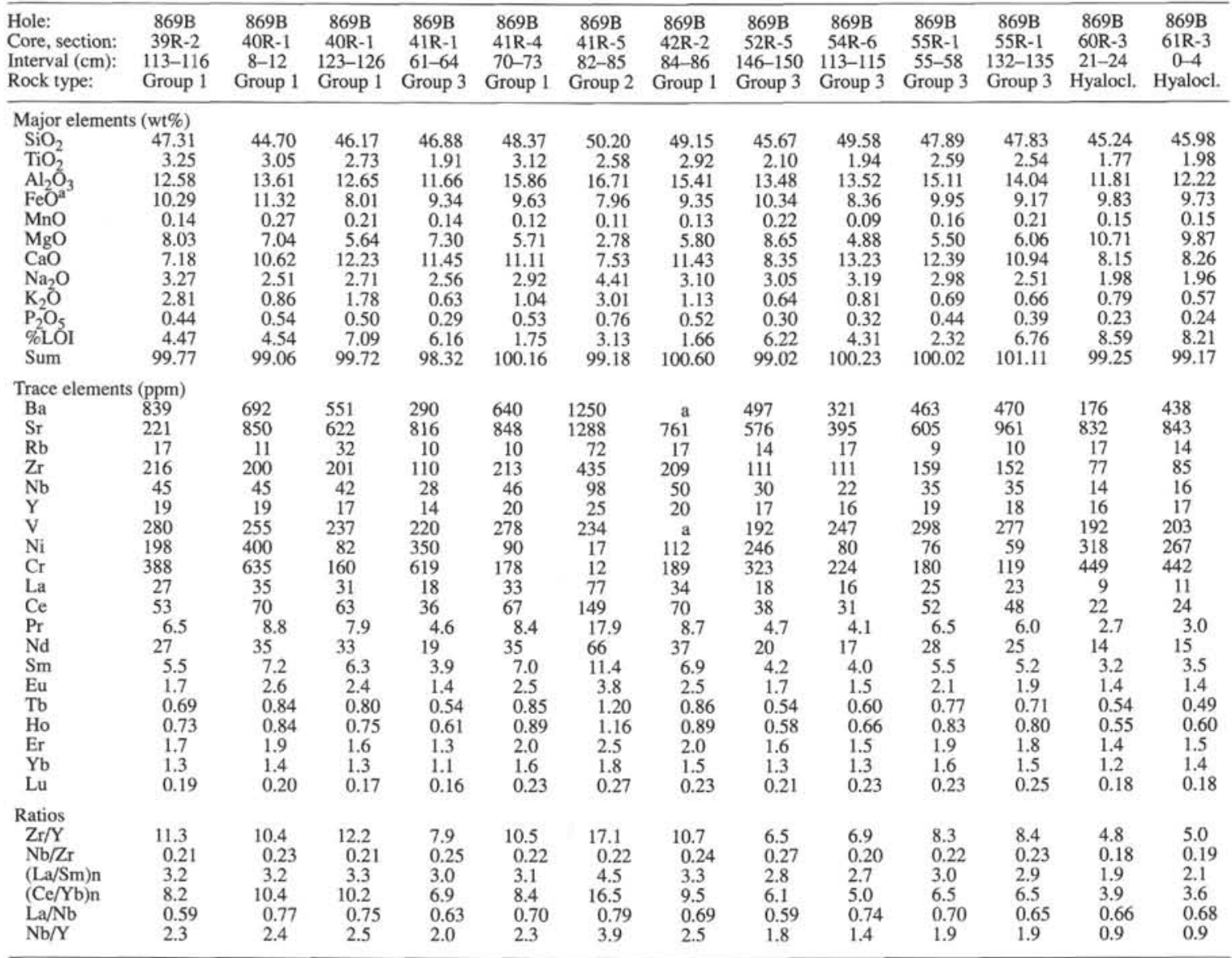

a Not determined.

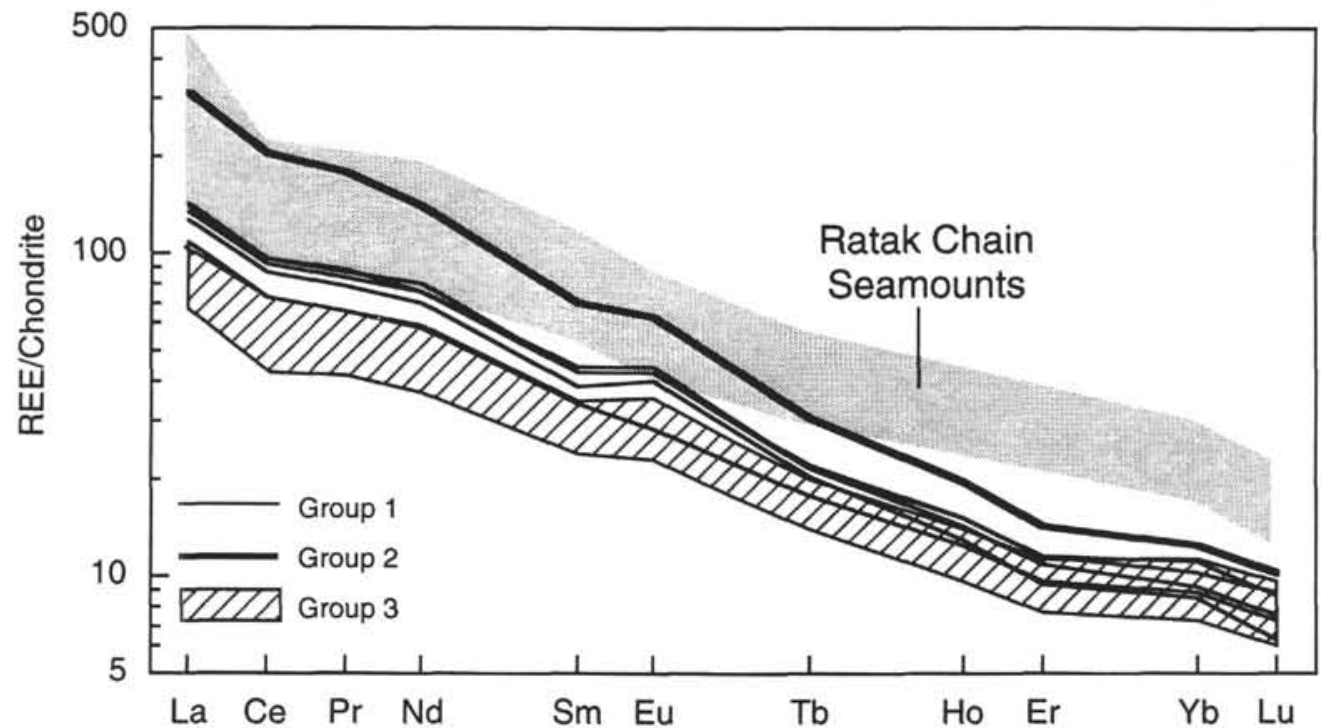

Figure 6. Chondrite-normalized REE values for the Site 869 lava clasts. The data are plotted by petrographic groups, as labeled. Chondrite values from Evensen et al. (1978). Note the small intragroup variation in REE concentrations. The background field is the range of REE values in lavas from Marshall Islands seamounts in the Ratak Chain (Davis et al., 1989). 


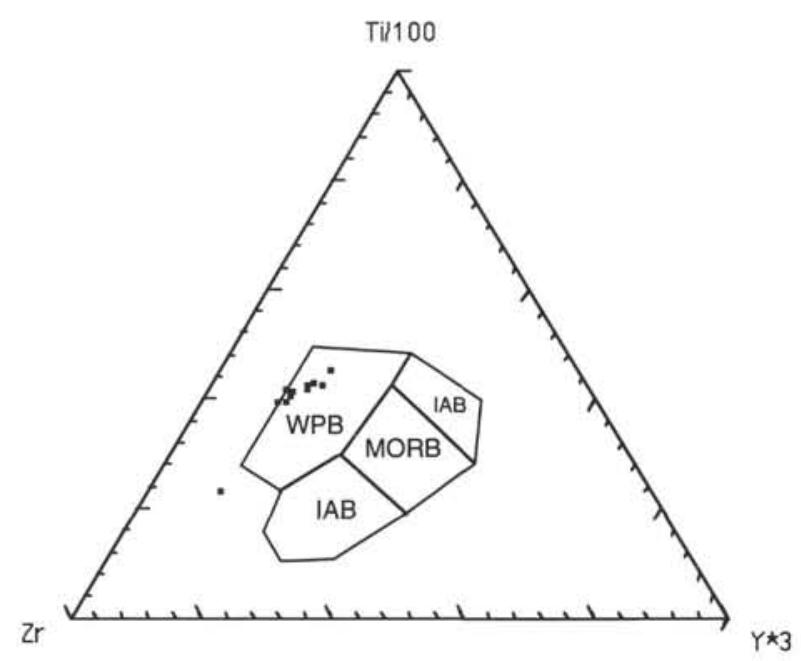

Figure 7. Distribution of Site 869 lava clasts on the tectonic discrimination diagram of Pearce and Cann (1973). WPB = within plate (intraplate) basalts, $\mathrm{IAB}=$ island arc basalts, $\mathrm{MORB}=$ mid-ocean ridge basalts.

Samoa and the high $\mu\left({ }^{238} \mathrm{U} /{ }^{204} \mathrm{~Pb}\right.$ ratio; HIMU) component with Mangaia and Tubuai. Hence, it appears that the source of the Site 869 clasts, and therefore the source of Pikinni/Wodejebato, may consist of a heterogeneous mixture of EMII and HIMU-type mantle material. Indeed, $\mathrm{Sr}, \mathrm{Nd}$, and $\mathrm{Pb}$ isotopic data on the clasts support this conclusion, forming an array intermediate between EMII and HIMU, but pointing toward both end-members $\left({ }^{87} \mathrm{Sr} /{ }^{86} \mathrm{Sr}_{\text {initial }}\right.$ ranges from 0.7037 to 0.7045 and ${ }^{206} \mathrm{~Pb} /{ }^{204} \mathrm{~Pb}$ ranges from 18.9 to 19.5 ; Castillo et al., unpubl. data).

\section{Comparison with Other Marshall Islands Seamounts}

Geochemical data about volcanic rocks from Marshall Islands atolls and guyots are limited. The only published data for the geochemistry of volcanic rocks from the Marshall Islands are of lavas dredged from Majuro Atoll, Erikub Seamount, and Bikar and Ratak guyots in the Ratak chain. These lavas are Santonian/Campanian (82-87 Ma) alkalic basalts, hawaiites, and melilitites (Davis et al., 1989). They are more alkalic than most of the clasts from Site 869 , which is evident in their higher average LREE, $\mathrm{Nb}$, and $\mathrm{Zr}$ contents (e.g., Figs. 6, 8, and 9). They also have shallower REE curves and higher HREE contents than the Site 869 lavas, suggesting a different mantle source.

$\mathrm{The} \mathrm{Nb} / \mathrm{Zr}$ and $\mathrm{La} / \mathrm{Nb}$ ratios of the lavas from the four dredged Ratak seamounts are plotted in Figure 11. The data form two groups: Majuro and Erikub, the two southern seamounts, have fairly low $\mathrm{Nb} / \mathrm{Zr}$ ratios and plot in and near the Samoan field; Bikar and Ratak, the two northern seamounts, have high $\mathrm{Nb} / \mathrm{Zr}$ ratios similar to those of Tubuai in the Cook-Austral Islands. This variation in $\mathrm{Nb} / \mathrm{Zr}$ ratios suggests that mantle source heterogeneity is a common feature in the Marshall Islands region.

It is important to note that mantle source compositions often change significantly between the lava series of a single volcano (Chen and Frey, 1985; Duncan et al., 1986; Desonie et al., 1993) and, therefore, elemental and isotopic ratios of lavas from one or two dredges on a seamount may not reflect the mantle composition of the entire edifice. Consequently, it may not be appropriate to treat the isotopic and $\mathrm{Nb} / \mathrm{Zr}$ ratios of the lavas dredged from a Ratak Chain seamount as representative of the seamount's entire mantle source(s), because these ratios may only reflect the source composition of one stage of volcanism.

Pikinni/Wodejebato is latitudinally located between the northern (apparently HIMU-like) and southern (apparently EMII-like) Ratak seamounts and has a mantle source composition that is intermediate

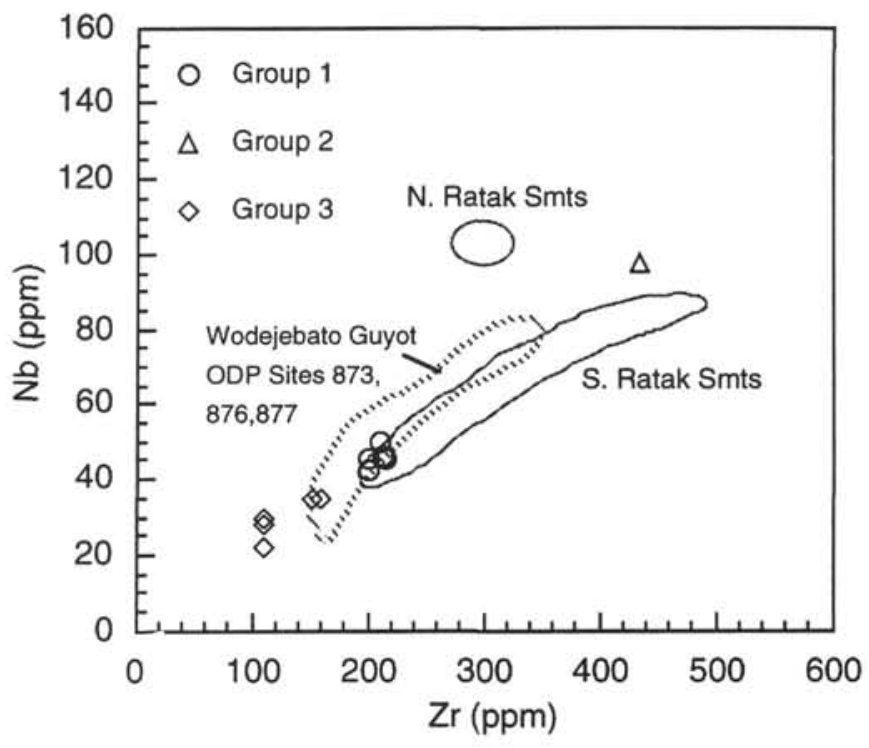

Figure $8 . \mathrm{Zr}$ vs. $\mathrm{Nb}$ for the 11 Site 869 clasts. Fields for data from the northern and southern Ratak chain seamounts from Davis et al. (1989). Field for data from Site 873, 876, and 877 lavas from Christie et al. (in press).

between EMII and HIMU. If we assume that the trace element and isotopic ratios of the lavas dredged from the 4 Ratak Chain seamounts are representative of the seamounts' respective mantle sources, then Pikinni/Wodejebato may have been situated over a transition zone between mantle material carrying the EMII and HIMU end-member signatures. Alternatively, if the elemental and isotopic ratios of the dredged Ratak lavas represent only the mantle source of one stage of volcanism on each Ratak Chain seamount, then the mantle sources of all of the sampled Marshall Seamounts may contain both the EMII and HIMU mantle end-members. Further detailed sampling and isotopic analysis of lavas from these seamounts must be conducted to validate either of these preliminary hypotheses.

Large variations in mantle source composition within individual islands and between islands and seamounts within a single hot-spot chain are not uncommon. A number of recent hot-spot chains with changes in mantle composition have been documented, particularly in the French Polynesia region of the south-central Pacific. The Marquesas Archipelago, for example, has islands that show a gradual transition from HIMU to EMII mantle components in successive lava series (Dupuy et al., 1987; Desonie et al., 1993). The Cook-Austral chain, which may have been created by the same hot spot(s) that created the Marshall Islands (Duncan and Clague, 1985), has islands that are dominated by EMI, EMII, and HIMU signatures (Palacz and Saunders, 1986; Nakamura and Tatsumoto, 1988). Whether the variations in mantle chemistry of the Marshall Islands seamounts were caused by temporal changes in the composition of the upwelling mantle plume, or by changes in how the plume interacted with the lithosphere and upper mantle, is unclear at the present time.

\section{Volcanism at Pikinni/Wodejebato}

Three of the Site 869 lava clasts have been dated using ${ }^{40} \mathrm{Ar} /{ }^{39} \mathrm{Ar}$ incremental heating techniques (Pringle and Duncan, this volume; see Table 1). They are all of Cenomanian age and span a range from approximately 94 to $96 \mathrm{Ma}$. The clasts are significantly older than the lavas dredged or drilled from the summit and upper flanks of Wodejebato Guyot, which are Campanian and have an age range of 79 to $85 \mathrm{Ma}$ (Pringle et al., 1993). The age difference between the older Site 869 clasts and the younger Wodejebato summit and flank lavas, in addition to the periodicity of volcanogenic sediment deposition, suggests that volcanism at Pikinni/Wodejebato occurred in two main phases. 

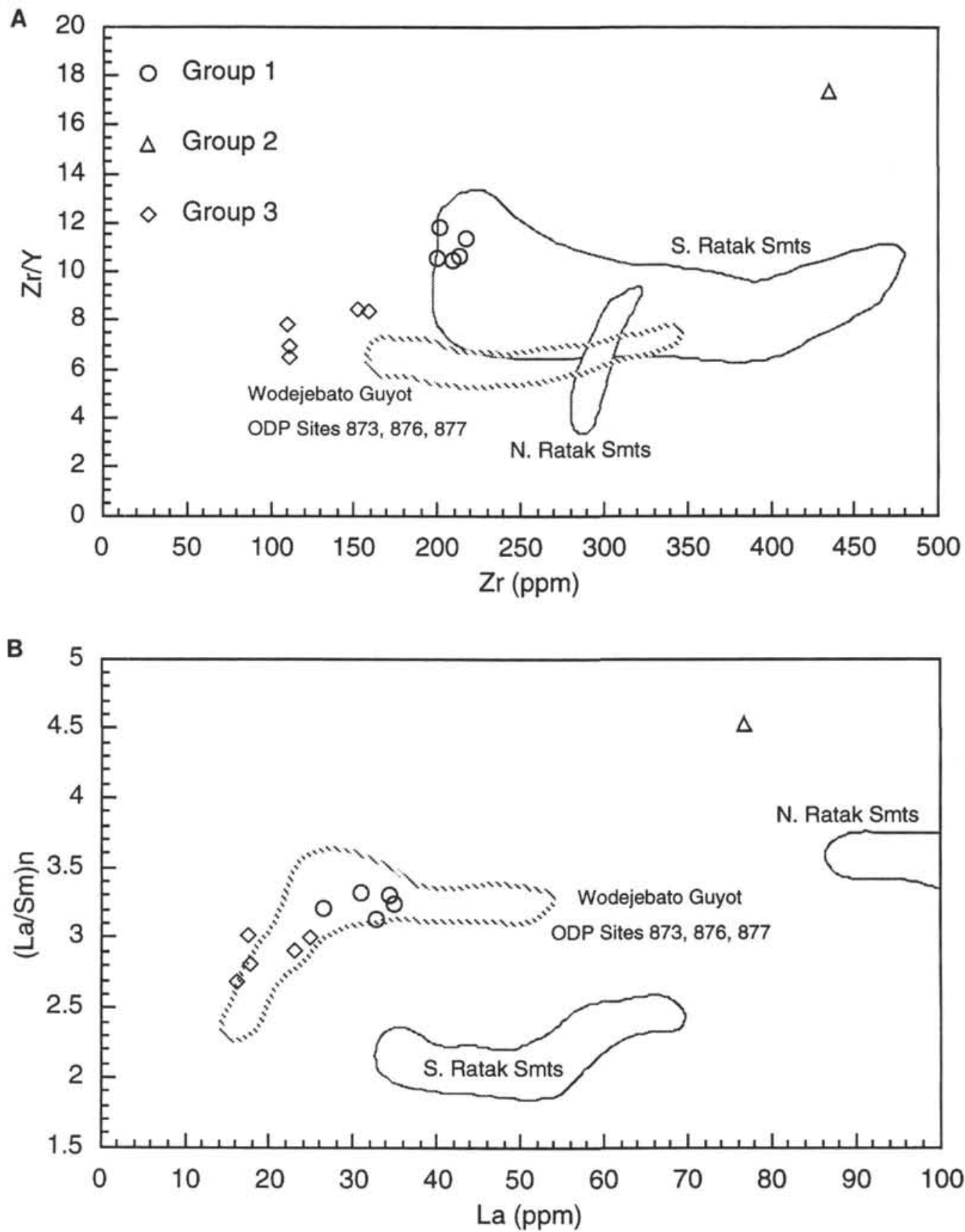

Figure 9. A. Zr vs. Zr/Y ratios for the 11 Site 869 clasts. B. La vs. chondrite-normalized La/Sm ratios for the 11 clasts. The fields for lavas from the Ratak Chain seamounts and Site 873, 876, and 877 lavas are cited in Figure 8. Field for data from Site 873, 876, and 877 lavas from Christie et al. (in press).

Deposition of the approximately $600 \mathrm{~m}$ of volcanogenic sediments at Site 869B occurred from middle Cenomanian to early Campanian/early Maastrichtian, estimated from nannofossil assemblages (Sager, Winterer, Firth, et al., 1993). The vast majority of the sediment was deposited in the Cenomanian and Campanian stages ( 328 and $174 \mathrm{~m}$, respectively) with little deposition occurring in the 6 to $7 \mathrm{~m} . \mathrm{y}$. between the two periods. The paleontologically dated Campanian volcaniclastics at Site 869 coincide with the ages of lavas from the summit and upper flanks of Wodejebato Guyot, which are also Campanian (Pringle et al., 1993).

Because the radiometric ages of the clasts agree to within a few million years with the paleontological ages of the sediments in which they lie (Pringle and Duncan, this volume; Sager, Winterer, Firth, et al., 1993), it is likely that most of the shedding and deposition of volcanic debris occurred concurrently with volcanism, as is thought to have occurred in other locations (e.g., Kelts and Arthur, 1981; Moore et al., 1989). Therefore, edifice-building volcanism at Pikinni// Wodejebato appears to have begun in the Cenomanian, followed by a 6- to 7-m.y. pause with little or no volcanic activity, and then concluded with a resurgence of volcanism in the Campanian, capping the edifice. If this is the case, then the Site 869 clasts are the products of the main stage of edifice-building volcanism in the Cenomanian. Further, this indicates that the "shield" portions of Pikinni/Wodejebato are composed of mildly to moderately alkalic lavas, which is thought to be true of a number of volcanoes in the French Polynesia region, particularly of those in the Cook-Austral Islands chain (Duncan and McDougall, 1976; Nakamura and Tatsumoto, 1988). The long time period between initiation and cessation of volcanism at Pikinni/ 


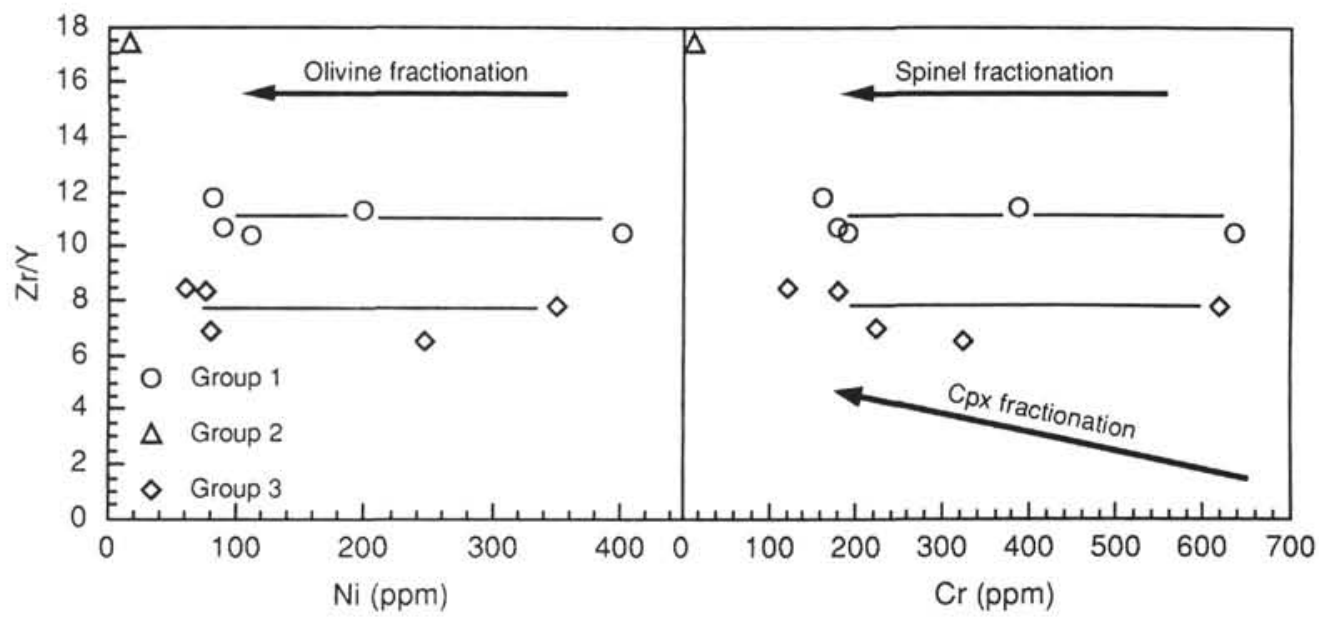

Figure 10. $\mathrm{Ni}$ and $\mathrm{Cr}$ concentrations vs. $\mathrm{Zr} / \mathrm{Y}$ ratios for the Site 869 lava clasts. Lines connect samples from same petrographic groups. Arrows indicate the fractionation trend for olivine, spinel, and clinopyroxene. Note the wide range of $\mathrm{Ni}$ and $\mathrm{Cr}$ values in Groups 1 and 3 (see text for discussion).

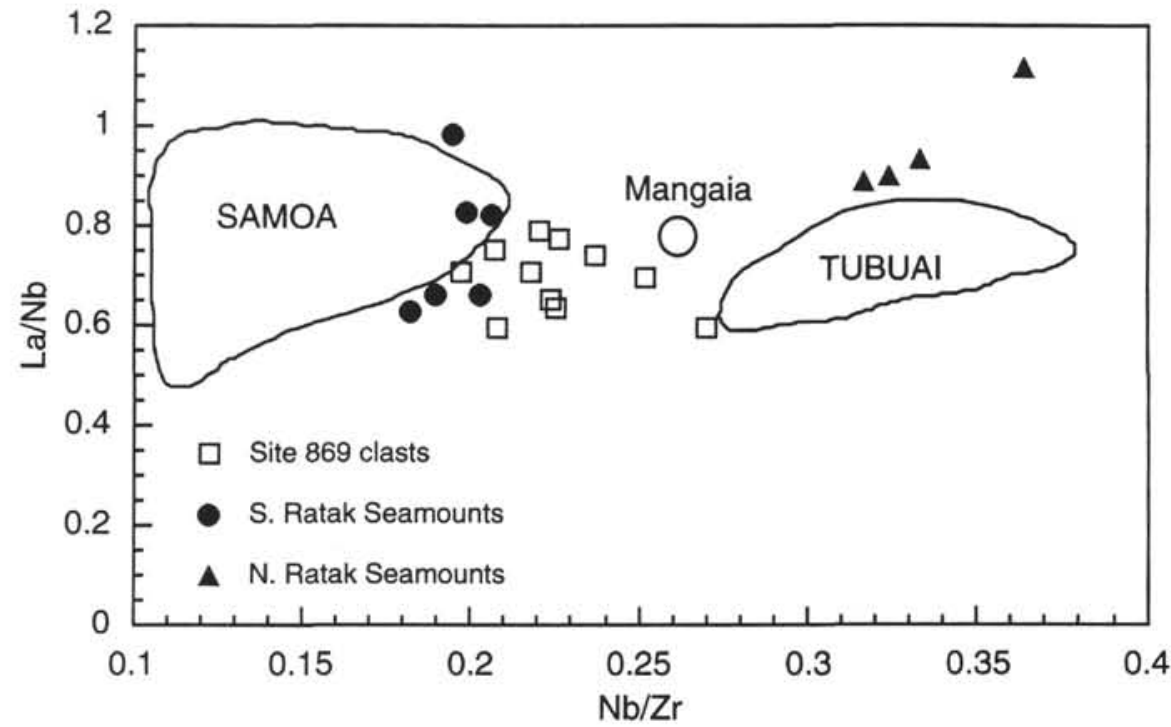

Figure 11. Nb/Zr vs. La/Nb for the Site 869 lava clasts. Symbols are as labeled (see text for discussion). Samoan field data are from Tutuila, American Samoa (Dieu, unpubl. data). Data for Tubuai from Chauvel et al. (1992), for Mangaia from Palacz and Saunders (1986), for Ratak Chain, Marshall Islands from Davis et al. (1989)

Wodejebato also is similar to the long time scales of volcanism on some of the Cook-Austral Islands (Duncan and McDougall, 1976).

Drilling of Campanian lavas on the summit of Wodejebato at Sites 873 through 877 during Leg 144 recovered alkalic basalts and hawaiites. Although most of the recovered lavas have been extremely altered (Premoli Silva, Haggerty, Rack, et al., 1993), many mineral and a few whole-rock geochemical data have been acquired during these cruises (Christie et al., in press; Dieu, in press).

The mineral compositions of lavas from Sites 873 through 877 overlap to a large degree with the phases from Site 869 lavas and hyaloclastites. The compositions of fresh clinopyroxene phenocrysts and groundmass grains from Sites 873 through 877 have compositional ranges broader than, but similar to, Site 869 clinopyroxenes, and almost all Site 869 clinopyroxene compositions fall within the field for clinopyroxenes from Sites 873 through 877 on the three clinopyroxene diagrams in Figure 4. Similarly, compositions of primary feldspar phenocrysts and groundmass grains from Sites 873 through 877 fall along a trend almost identical to the plagioclase data from Site 869 , but again with a broader range of compositions (35.20-78.3 mol\% An; 0.23-5.07 mol\% Or; Dieu, in press).
Concentrations of $\mathrm{Nb}, \mathrm{Zr}$, and the REE in six lavas from Sites 873 , 876 , and 877 are also similar to the average composition of the Site 869 lava clasts (Christie et al., in press; see Figs. 8 and 9). The similarity in mineral and whole rock compositions between the Campanian lavas from Sites 873 through 877 and the Cenomanian lavas from Site 869 strongly suggests that no significant differences exist in the conditions of melting or extents of fractionation between the "shield" and "post-erosional" lavas of Pikinni/Wodejebato.

\section{CONCLUSIONS}

Eleven basaltic clasts and 12 hyaloclastites were examined from volcaniclastic sediments at Site 869, located on the archipelagic apron southwest of Pikinni Atoll and Wodejebato Guyot. These clasts are mildly to moderately alkalic basalts and hawaiites. The clasts are classified into three groups based on phenocryst assemblages and textural characteristics: Group 1 (five samples) is moderately to highly clinopyroxene, olivine, and plagioclase phyric; Group 2 (one sample) is moderately hornblende, clinopyroxene, and plagioclase phyric; and Group 3 (five samples) is moderately clinopyroxene and plagioclase 
phyric. The hyaloclastites are composed of glass shards and lapilli, many with pristine olivine phenocrysts, mineral fragments, and sparse lithic fragments bound in a matrix of zeolite minerals. Mineral compositions are typical of phases crystallized from mafic to moderately fractionated alkalic melts in a hot-spot setting.

The clasts are enriched in the light rare-earth elements and have the high incompatible element concentrations typical of alkalic ocean island basalts (OIB). They form sloping linear arrays on incompatible element vs. incompatible element and incompatible element vs. H/M ratio diagrams (Figs. 9 and 10) from the Group 3 basalts having the lowest incompatible element contents and ratios to the Group 2 hawaiite having the highest. These arrays appear to be controlled by both variations in degree of partial melting and by changes in the composition of the mantle source.

The clasts have undergone small to moderate degrees of crystal fractionation, with olivine and spinel probably making up the early fractionating assemblage and clinopyroxene fractionation likely occurring later on. Positive Eu anomalies are common, suggesting that most samples experienced some plagioclase accumulation or that their source has a positive Eu anomaly.

Trace element ratios in the clasts, especially $\mathrm{Nb} / \mathrm{Zr}$, suggest that the mantle source of the clasts was enriched relative to MORB and heterogeneous, with compositions ranging from Samoa- to Tubuailike (i.e., from EMII to HIMU). This type of mantle source variation is consistent with isotopic data on the Site 869 clasts (Castillo et al., unpubl. data) and is a fairly common phenomenon in Pacific hot-spot chains in the French Polynesia region of the south central Pacific.

Radiometric and paleontological ages of the volcaniclastic sediments at Site 869, in addition to temporal variations in the amount of volcaniclastic sediment deposited, lead us to believe that volcanism at Pikinni/Wodejebato occurred in two main stages: the main edificebuilding stage in the Cenomanian, of which the Site 869 clasts are a product, and a volcanic resurgence 6 to 7 m.y. later in the Campanian (Pringle and Duncan, this volume; Pringle et al., 1993). Further, this hypothesis indicates that the shields of the Pikinni/Wodejebato edifices are composed of mildly to moderately alkalic lavas, which is thought also to be true of several volcanoes in the French Polynesia region.

\section{ACKNOWLEDGMENTS}

We thank R. Laborde, C. Roudin, and E. Condliffe for their assistance with the ICP-MS, microprobe, and XRF instruments. We are also grateful to J. Dieu for many productive discussions and for sharing her unpublished trace-element data on Samoan lavas. Peter Floyd and Michael Garcia provided thoughtful and scholarly reviews that greatly improved the quality of this manuscript.

\section{REFERENCES}

Allegré, C.J., Treuil, M., Minster, J., Minster, B., and Albarede, F., 1977. Systematic use of trace elements in igneous processes, Part I: fractional crystallization processes in volcanic suites. Contrib. Mineral. Petrol., 60:57-75.

Alt, J.C., and Emmermann, R., 1985. Geochemistry of hydrothermally altered basalts: Deep Sea Drilling Project Hole 504B. In Anderson, R.N., Honnorez, J., Becker, K., et al., Init. Repts. DSDP, 83: Washington (U.S. Govt. Printing Office), 249-262.

Alt, J.C., Honnorez, J., Laverne, C., and Emmermann, R., 1986. Hydrothermal alteration of a $1 \mathrm{~km}$ section through the upper oceanic crust, Deep Sea Drilling Project Hole 504B: mineralogy, chemistry, and evolution of seawater-basalt interactions. J. Geophys. Res., 91:10309-10335.

Basaltic Volcanism Study Project (BSVP), 1981. Basaltic Volcanism on the Terrestrial Planets: New York (Pergamon Press).

\footnotetext{
Abbreviations for names of organizations and publications in ODP reference lists follow the style given in Chemical Abstracts Service Source Index (published by American Chemical Society).
}

Bergersen, D.D., 1993. Geology and geomorphology of Wodejebato (Sylvania) Guyot, Marshall Islands. In Pringle, M.S., Sager, W.W., Sliter, W.V., and Stein, S. (Eds.), The Mesozoic Pacific: Geology, Tectonics, and Volcanism. Geophys. Monogr., Am. Geophys. Union, 77:367-385.

Bienvenu, P., Bougault, H., Joron, J.L., Treuil, M., and Dmitriev, L., 1990. MORB alteration: rare-earth element/non-rare-earth hygromagmaphile element fractionation. Chem. Geol., 82:1-14.

Cann, J.R., 1970. Rb, Sr, Y, Zr, and $\mathrm{Nb}$ in some ocean floor basaltic rocks. Earth Planet. Sci. Lett., 10:7-11.

Chauvel, C., Hofmann, A.W., and Vidal, P., 1992. HIMU-EM: the French Polynesian connection. Earth Planet. Sci. Lett., 110:99-109.

Chen, C.-Y., and Frey, F.A., 1985. Trace element and isotopic geochemistry of lavas from Haleakala Volcano, East Maui, Hawaii: implications for the origin of Hawaiian basalts. J. Geophys. Res., 90:8743-8768.

Chen, C.-Y., Frey, F.A., and Garcia, M.O., 1990. Evolution of alkalic lavas at Haleakala Volcano, East Maui, Hawaii. Contrib. Mineral. Petrol., 105:197-218

Christie, D.M., Dieu, J.J., and Gee, J., in press. Petrologic studies of basement lavas from Northwest Pacific guyots, ODP Leg 144. In Haggerty, J.A., Premoli Silva, I., Rack, F., and McNutt, M.K. (Eds.), Proc. ODP, Sci. Results 144: College Station, TX (Ocean Drilling Program),

Clague, D.A., 1974. The Hawaiian-Emperor Seamount Chain: its origin, petrology and implications for plate tectonics [Ph.D. dissert.]. Univ. of Calif., San Diego.

Clague, D.A., Fisk, M.R., and Bence, A.E., 1980. Mineral chemistry of basalts from Ojin, Nintoku, and Suiko Seamounts Leg 55 DSDP. In Jackson, E.D., Koizumi, I., et al., Init. Repts. DSDP, 55: Washington (U.S. Govt. Printing Office), 607-637.

Davis, A.S., Pringle, M.S., Pickthorn, L.B.G., Clague, D.A., and Schwab, W.C., 1989. Petrology and age of alkalic lava from the Ratak chain of the Marshall Islands. J. Geophys. Res., 94:5757-5774.

Desonie, D.L., Duncan, R.A., and Natland, J.H., 1993. Temporal and geochemical variability of volcanic products of the Marquesas Hotspot. $J$. Geophys. Res., 98:17649-17665.

Dieu, J.J., in press. Results of electron and ion microprobe analyses of phenocrysts and xenoliths in ODP Leg 144 lavas. In Haggerty, J.A., Premoli Silva, I., Rack, F., and McNutt, M.K. (Eds.), Proc. ODP, Sci. Results, 144: College Station, TX (Ocean Drilling Program).

Duncan, R.A., and Clague, D.A., 1985. Pacific plate motion recorded by linear volcanic chains. In Nairn, A.E.M., Stehli, F.G., and Uyeda, S. (Eds.), The Ocean Basins and Margins (Vol. 7A): The Pacific Ocean: New York (Plenum), 89-121.

Duncan, R.A., McCulloch, M.T., Barsczus, H.G., and Nelson, D.R., 1986. Plume versus lithospheric sources for melts at Ua Pou, Marquesas Islands. Nature, 322:534-538.

Duncan, R.A., and McDougall, I., 1976. Linear volcanism in French Polynesia. J. Volcanol. Geotherm. Res., 1:197-227.

Dupuy, C., Vidal, P., Barczus, H.G., and Chauvel, C., 1987. Origin of basalts from the Marquesas Archipelago (south central Pacific Ocean): isotope and trace element constraints. Earth Planet. Sci. Lett., 82:145-152.

Erlank, A.J., and Kable, E.J.D., 1976. The significance of incompatible elements in Mid-Atlantic Ridge basalts from $45^{\circ} \mathrm{N}$, with particular reference to Zr/Nb. Contrib. Mineral. Petrol., 54:281-291.

Evensen, N.M., Hamilton, P.J., and O'Nions, R.K., 1978. Rare-earth abundances on chondritic meteorites. Geochim. Cosmochim. Acta., 42:11991212 .

Falloon, T.J., Green, D.H., Hatton, C.J., and Harris, K.L., 1988. Anhydrous partial melting of a fertile and depleted peridotite from 2 to $30 \mathrm{~kb}$ and application to basalt petrogenesis. J. Petrol., 29:1257-1282.

Floyd, P.A., 1986. Glassy and basaltic fragments within graded volcaniclastic sediments, East Mariana Basin, Deep Sea Drilling Project Leg 89. In Moberly, R., Schlanger, S.O., et al., Init. Repts. DSDP, 89: Washington (U.S. Govt. Printing Office), 433-447.

Fodor, R.V., Keil, K., and Bunch, T.E., 1975. Contributions to the mineral chemistry of Hawaiian rocks: IV - pyroxenes in rocks from Haleakala and West Maui Volcanoes. Contrib. Mineral. Petrol., 50:173-195.

Frey, F.A., Wise, W.S., Garcia, M.O., West, H., Kwon, S.-T., and Kennedy, A., 1990. Evolution of Mauna Kea Volcano, Hawaii: petrologic and geochemical constraints on postshield volcanism. J. Geophys. Res., 95:1271-1300.

Garcia, M.O., Frey, F.A., and Grooms, D.G., 1986. Petrology of volcanic rocks from Kaula Island, Hawaii. Contrib. Mineral. Petrol., 94:461-471.

Hart, S.R., and Dunn, T., 1993. Experimental CPX/melt partitioning of 24 trace elements. Contrib. Mineral. Petrol., 113:1-8. 
Hart, S.R., Erlank, A.J., and Kable, E.J.D., 1974. Sea floor basalt alteration: some chemical and $\mathrm{Sr}$ isotopic effects. Contrib. Mineral. Petrol., 44:219230.

Kelts, K., and Arthur, M.A., 1981. Turbidites after ten years of deep-sea drilling - wringing out the mop? In Warme, J.E., Douglas, R.G., and Winterer, E.L. (Eds.), The Deep Sea Drilling Project: A Decade of Progress. Spec. Publ.-Soc. Econ. Paleontol. Mineral., 32:91-127.

King, A.J., Waggoner, D.G., and Garcia, M.O., in press. Geochemistry and petrology of basalts from ODP Leg 136. Central Pacific Ocean. Earth Planet. Sci. Lett.

Le Bas, M.J., 1962. The role of aluminum in igneous clinopyroxenes with relation to their parentage. Am. J. Sci., 260:267-288.

le Roex, A.P., 1986. Geochemical correlations between Southern African kimberlites and South Atlantic hot-spots. Nature, 324:243-245.

Lincoln, J.M., Pringle, M.S., and Premoli-Silva, I., 1993. Early and Late Cretaceous volcanism and reef-building in the Marshall Islands. In Pringle, M.S., Sager, W.W., Sliter, W.V., and Stein, S. (Eds.), The Mesozoic Pacific: Geology, Tectonics, and Volcanism. Geophys. Monogr., Am. Geophys. Union, 77:279-305.

Macdonald, G.A., and Katsura, T., 1964. Chemical composition of Hawaiian lavas. J. Petrol., 5:82-133.

Minster, J.F., and Allegré, C.J., 1978. Systematic use of trace elements in igneous processes. Part III: inverse problem of batch partial melting in volcanic suites. Contrib. Mineral. Petrol., 68:37-52.

Moore, J.G., Clague, D.A., Holcomb, R.T., Lipman, P.W., Normark, W.R., and Torresan, M.E., 1989. Prodigious submarine landslides on the Hawaiian Ridge. J. Geophys. Res., 94:17465-17484.

Mottl, M.J., and Holland, H.D., 1978. Chemical exchange during hydrothermal alteration of basalt by seawater. I. Experimental results for major and minor components of seawater. Geochim. Cosmochim. Acta, 42:1103-1115.

Nakamura, Y., and Tatsumoto, M., 1988. Pb, Nd and $\mathrm{Sr}$ isotopic evidence for a multicomponent source for rocks of Cook-Austral Islands and heterogeneities of mantle plumes. Geochim. Cosmochim. Acta, 52:2909-2924.

Norrish, K., and Hutton, J.T., 1969. An accurate X-ray spectrographic method for the analysis of a wide range of geological samples. Geochim. Cosmochim. Acta, 33:431-453.

Palacz, Z.A., and Saunders, A.D., 1986. Coupled trace element and isotope enrichment in the Cook-Austral-Samoa islands, southwest Pacific. Earth Planet. Sci. Lett., 79:270-280.

Pearce, J.A., and Cann, J.R., 1973. Tectonic setting of basic volcanic rocks determined using trace element analyses. Earth Planet. Sci. Lett., 19:290300.
Pearce, J.A., and Norry, M.J., 1979. Petrogenetic implications of Ti, Zr, Y, and $\mathrm{Nb}$ variations in volcanic rocks. Contrib. Mineral. Petrol., 69:33-47.

Premoli Silva, I., Haggerty, J., Rack, et al., 1993. Proc. ODP, Init. Repts., 144: College Station, TX (Ocean Drilling Program).

Pringle, M.S., Staudigel, H., Duncan, R.A., and Christie, D.M., 1993. ${ }^{40} \mathrm{Ar}{ }^{39} \mathrm{Ar}$ ages of basement lavas at Resolution, MIT, and Wodejebato guyots compared with magneto- and bio-stratigraphic results from ODP Leg 143/144. Eos, 74:353.

Reed, S.J.B., 1975. Electron Microprobe Analysis: Cambridge (Cambridge Univ. Press).

Sager, W.W., Winterer, E.L., Firth, J.V., et al., 1993. Proc. ODP, Init. Repts., 143: College Station, TX (Ocean Drilling Program).

Sen, G., and Presnall, D.C., 1986. Petrogenesis of dunite xenoliths from Koolau Volcano, Oahu, Hawaii: implications for Hawaiian volcanism. $J$. Petrol., 27:197-217.

Staudigel, H., and Hart, S.R., 1983. Alteration of basaltic glass: mechanisms and significance of the oceanic crust-seawater budget. Geochim. Cosmochim. Acta, 47:337-350.

Verma, S.P., 1992. Seawater alteration effects on REE, K, Rb, Cs, Sr, U, Th, $\mathrm{Pb}$ and $\mathrm{Sr}-\mathrm{Nd}-\mathrm{Pb}$ isotope systematics of mid-ocean ridge basalt. Geochem. J., 26:159-177.

Weaver, B.L., 1991. The origin of ocean island basalt end-member compositions: trace element and isotopic constraints. Earth Planet. Sci. Lett., 104:381-397.

White, W.M., and Hofmann, A.W., 1982. Sr and Nd isotope geochemistry of oceanic basalts and mantle evolution. Nature, 296:821-825.

Winchester, J.A., and Floyd, P.A., 1976. Geochemical magma type discrimination: application to altered and metamorphosed basic igneous rocks. Earth Planet. Sci. Lett., 28:459-469.

Yoder, H.S., and Tilley, C.E., 1962. Origin of basaltic magmas: an experimental study of natural and synthetic rock systems. J. Petrol., 3:342-532.

Zindler, A., and Hart, S., 1986. Chemical geodynamics. Annu. Rev. Earth Planet. Sci., 14:493-571.

Date of initial receipt: 1 December 1993

Date of acceptance: 6 July 1994

Ms 143SR-217 